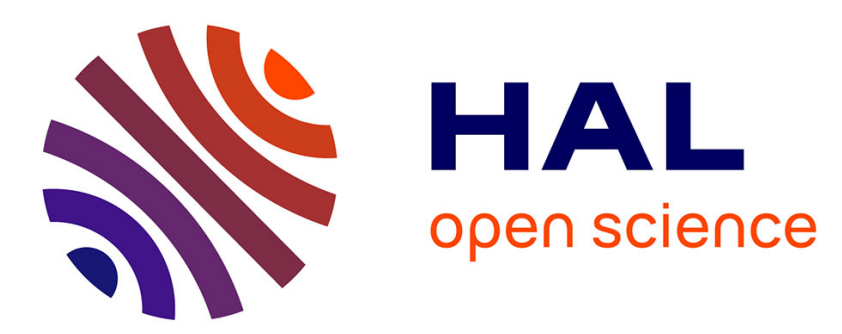

\title{
Catalytic transformation of carbon dioxide and methane into syngas over ruthenium and platinum supported hydroxyapatites
}

Bruna Rego de Vasconcelos, Lulu Zhao, Patrick Sharrock, Ange Nzihou, Doan Pham Minh

\section{To cite this version:}

Bruna Rego de Vasconcelos, Lulu Zhao, Patrick Sharrock, Ange Nzihou, Doan Pham Minh. Catalytic transformation of carbon dioxide and methane into syngas over ruthenium and platinum supported hydroxyapatites. Applied Surface Science, 2016, 390, pp.141-156. 10.1016/j.apsusc.2016.08.077 . hal-01609114

\section{HAL Id: hal-01609114 https://hal.science/hal-01609114}

Submitted on 24 Oct 2018

HAL is a multi-disciplinary open access archive for the deposit and dissemination of scientific research documents, whether they are published or not. The documents may come from teaching and research institutions in France or abroad, or from public or private research centers.
L'archive ouverte pluridisciplinaire HAL, est destinée au dépôt et à la diffusion de documents scientifiques de niveau recherche, publiés ou non, émanant des établissements d'enseignement et de recherche français ou étrangers, des laboratoires publics ou privés. 


\title{
Catalytic transformation of carbon dioxide and methane into syngas over ruthenium and platinum supported hydroxyapatites
}

\author{
Bruna Rêgo De Vasconcelos, Lulu Zhao, Patrick Sharrock, Ange Nzihou, Doan Pham Minh*
}

Université de Toulouse, Mines Albi, CNRS UMR 5302, Centre RAPSODEE, Albi, France

\section{A B S T R A C T}

This work focused on the catalytic transformation of methane $\left(\mathrm{CH}_{4}\right)$ and carbon dioxide $\left(\mathrm{CO}_{2}\right)$ into syngas (mixture of $\mathrm{CO}$ and $\mathrm{H}_{2}$ ). Ruthenium- and platinum-based catalysts were prepared using hydroxyapatite (HAP) as catalyst support. Different methods for metal deposition were used including incipient wetness impregnation (IWI), excess liquid phase impregnation (LIM), and cationic exchange (CEX). Metal particle size varied in large range from less than $1 \mathrm{~nm}$ to dozens $\mathrm{nm}$. All catalysts were active at $400-700{ }^{\circ} \mathrm{C}$ but only Pt catalyst prepared by IWI method (Pt/HAP IWI) was found stable. The catalytic performance of Pt/HAP IWI could be comparable with the literature data on noble metal-based catalysts, prepared on metal oxide supports. For the first time, water was experimentally quantified as a by-product of the reaction. This helped to correctly buckle the mass balance of the process.

Keywords:

Hydroxyapatite

Ruthenium catalyst

Platinum catalyst

Methane

Carbon dioxide

Syngas

\section{Introduction}

Synthesis gas, or syngas, is a gas mixture containing mainly carbon monoxide $(\mathrm{CO})$ and hydrogen $\left(\mathrm{H}_{2}\right)$. Commercialized firstly in 1800 s by the London Gas, Light, and Coke Company, syngas has nowadays several applications for illuminating cities, providing heat and power, fueling vehicles through both direct use with gas engine, and conversion to liquid fuels, as well as for obtaining chemicals or intermediates by different chemical or biological transformation processes $[1,2]$. By catalytic way, syngas can be converted into other platform molecules or final products such as methanol, ethanol, aldehydes, waxes, diesel, olefins, gasoline, electricity, etc. [1,3].

Syngas can be obtained from the gasification of coal, wood, agricultural and forestry residues, and biomass-containing wastes [4]. Gasification process takes place at high temperature (up to about $1000^{\circ} \mathrm{C}$ ), using different atmospheres of vapor, carbon dioxide, nitrogen, oxygen, or mixture of these components. Gas product of this process needs to be purified by suitable technologies as a function of its use [5].

\footnotetext{
* Corresponding author.

E-mail addresses: doan.phamminh@mines-albi.fr, doanhoa2000@yahoo.fr (D. Pham Minh)
}

Syngas can also be obtained from the reforming of light hydrocarbons such as methane. Different oxidants can be used, in particular oxygen and carbon dioxide. Thus, catalytic partial oxidation of methane to syngas using molecular oxygen can be selectively carried out over highly dispersed nickel supported ceria $\left(\mathrm{Ni} / \mathrm{CeO}_{2}\right)$, according to Eq. (1) [6]. Both the conversion of methane and the selectivity into $\mathrm{CO}$ reached more than $90 \%$ above $650{ }^{\circ} \mathrm{C}$ for a mixture having the molar ratio of methane to oxygen equal to 2. Previously, Choudhary et al. showed that $\mathrm{Co} / \mathrm{MgO}$ catalyzed selectively the oxidation of methane by molecular oxygen into syngas with $75 \%$ of methane conversion and $90-91 \%$ of $\mathrm{CO}$ and $\mathrm{H}_{2}$ selectivity at $700{ }^{\circ} \mathrm{C}[7]$.

$$
\begin{aligned}
& \mathrm{CH}_{4}+1 / 2 \mathrm{O}_{2} \rightarrow \mathrm{CO}+2 \mathrm{H}_{2} \Delta \mathrm{H}^{\circ}{ }_{298}=-36 \mathrm{~kJ} \mathrm{~mol}^{-1} \\
& \mathrm{CH}_{4}+\mathrm{CO}_{2} \rightarrow 2 \mathrm{CO}+2 \mathrm{H}_{2} \Delta \mathrm{H}^{\circ}{ }_{298}=247 \mathrm{~kJ} \mathrm{~mol}^{-1}
\end{aligned}
$$

Using $\mathrm{CO}_{2}$ as oxidant, methane can also be reformed into syngas by catalytic way, according to Eq. (2). Nickel-based catalysts seemed to be the most appropriate for this reaction. Boukha et al. showed that an equimolar mixture of $\mathrm{CH}_{4}$ and $\mathrm{CO}_{2}$ was quasitotally converted at high temperature $\left(650-800^{\circ} \mathrm{C}\right)$ with high selectivity into syngas over nickel supported on phosphate-based supports [8]. High performance of nickel supported on alumina and alumina-aluminum phosphate was also obtained at the temperature range of $750-800^{\circ} \mathrm{C}$ for this catalytic process [9]. Nickel-based catalysts supported on other supports such as ceria-zirconia, zeo- 

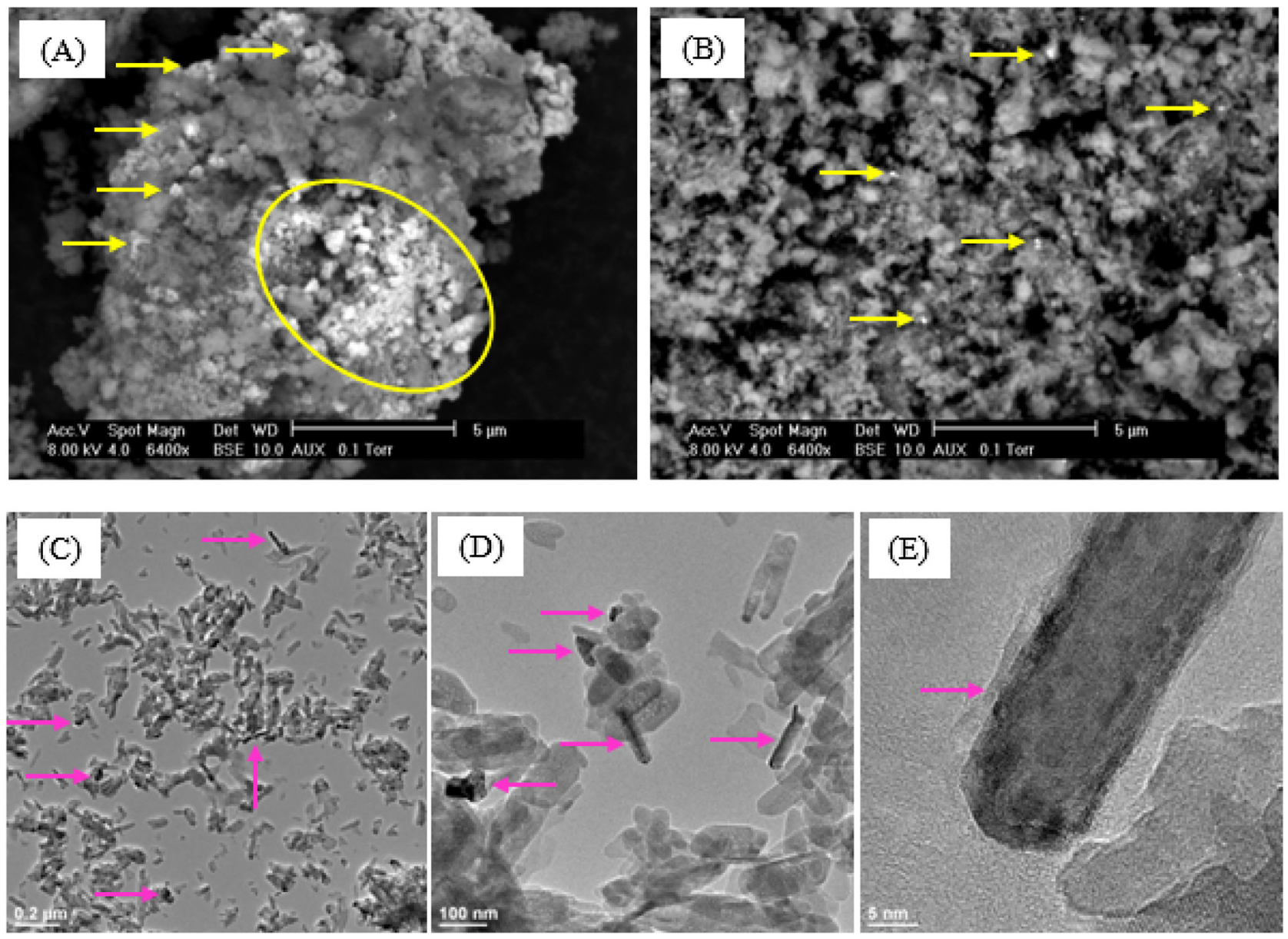

Fig. 1. SEM (A, B) and TEM (C, D, E) images of Ru/HAP IWI; yellow and pink arrows: Ru-based particles; yellow circle: Ru-based agglomerate. (For interpretation of the references to colour in this figure legend, the reader is referred to the web version of this article.)

lite, manganese oxide, silica, magnesium oxide, carbon nanotube, mixture of zirconia-silica oxides, hydrotalcite, $\mathrm{Mo}_{2} \mathrm{C}$, etc. were generally found to be active for the conversion of $\mathrm{CO}_{2} / \mathrm{CH}_{4}$ mixture at high temperatures, and with high selectivity in syngas product [10-19]. Other active metals such as cobalt, copper, ruthenium, and rhodium were also studied in the reforming of methane by carbon dioxide, which showed high catalytic performances [20-22].

Syngas formation from catalytic conversion of a mixture of methane and carbon dioxide seems to be pertinent from point of view of the sustainable development concept. In fact, methane and carbon dioxide are the two main components of biogas and natural gas. This process offers new valorizations of biogas and natural gas including the transformation of carbon dioxide into useful products. However, to the best of our knowledge, this catalytic process has not been developed at large industrial scale yet. This may be related to the fact that the reaction of methane with carbon dioxide into syngas is highly endothermic (Eq. (2)). In fact, the $\mathrm{C}=\mathrm{O}$ bond energy in carbon dioxide molecule is $724 \mathrm{~kJ} \mathrm{~mol}^{-1}$ [23], so the transformation of this molecule must be activated. High temperature, typically in the range of $650-950^{\circ} \mathrm{C}$, is needed for getting high catalytic conversion of methane and carbon dioxide into syngas. This temperature range leads to high energy consumption, and also to the deactivation of catalyst. The deactivation is principally due to coke deposition from side reactions such as methane cracking, reverse water-gas-shift, as well as to the sintering of both active phase and catalyst support. For example, using TEM analysis, Tsyganok et al. highlighted coke deposition on the surface of a nickel-based catalyst [24]. This deposition could reach up to $9.9 \mathrm{wt} . \%$. Most of the larger nickel particles $(15-35 \mathrm{~nm})$ were encapsulated with graphitic layers. High energy consumption and catalytic deactivation appear as the main drawbacks of the dry reforming of methane for industrial scale-up.

This work is devoted to the synthesis of hydroxyapatite supported ruthenium or platinum catalysts, and to the investigation of their catalytic performance in the transformation of methane and carbon dioxide into syngas. Ruthenium and platinum are well known as active phases in different catalytic reactions, in particular for reforming processes. Hydroxyapatite is chosen as support material by its thermal stability, and also by its possible high specific surface area, and its basicity properties [25]. The formation of ruthenium and platinum particles on HAP surface using different synthesis methods, and the reactivity of the prepared ruthenium and platinum catalysts are discussed. We have been also successful in the quantification of water formed during the dry reforming of methane process. To the best of our knowledge, the quantification of water has never been previously reported in the literature for this process. This allows establishing correctly the mass balance of the process since it was formed at a non-negligible amount in this reaction.

\section{Materials and methods}

\subsection{Catalyst preparation}

Hydroxyapatite powder was synthesized by the conventional precipitation method using orthophosphoric acid and calcium 

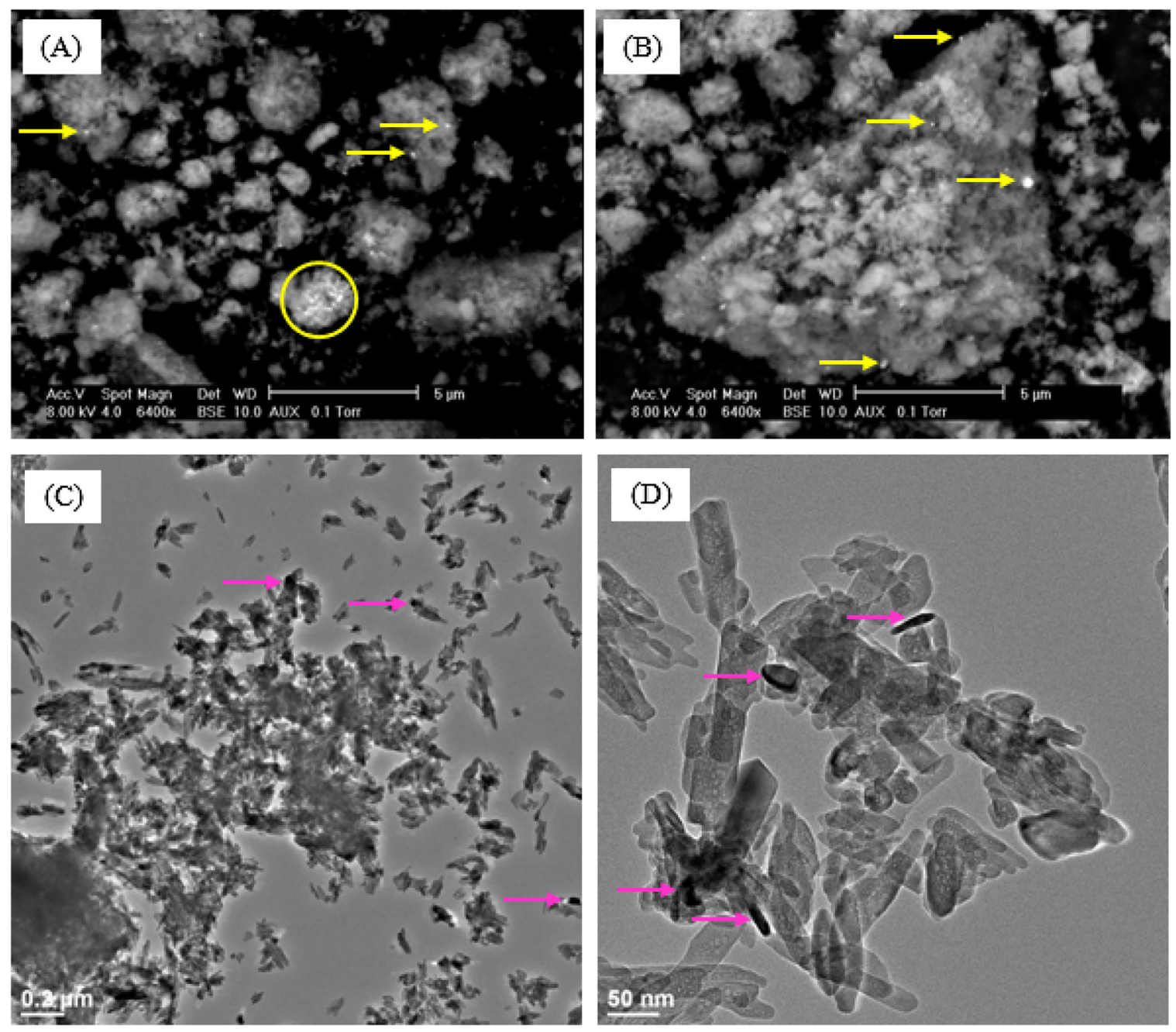

Fig. 2. SEM (A, B) and TEM (C, D) images of Ru/HAP CEX; yellow and pink arrows: Ru-based particles; yellow circle: Ru-based agglomerate. (For interpretation of the references to colour in this figure legend, the reader is referred to the web version of this article.)

Table 1

Catalysts prepared in this work.

\begin{tabular}{lll}
\hline Catalyst & Metal deposition & Pre-treatment \\
\hline Pt/HAP IWI & Incipient wetness impregnation & Air calcination at $400^{\circ} \mathrm{C}$ \\
Pt/HAP LIM & Liquid impregnation & Drying only at $105^{\circ} \mathrm{C}$ \\
Ru/HAP IWI & Incipient wetness impregnation & Air calcination at $400^{\circ} \mathrm{C}$ \\
Ru/HAP CEX & Cationic exchange & Air calcination at $400^{\circ} \mathrm{C}$ \\
\hline
\end{tabular}

hydroxide. Briefly, orthophosphoric acid (85 wt.\% in water, p.a.) was progressively added to an aqueous suspension of calcium hydroxide. The final molar ratio of calcium to phosphorus was fixed at 1.67. The reaction mixture was kept at $80^{\circ} \mathrm{C}$ for $2 \mathrm{~h}$ under stirring $(500 \mathrm{rpm})$. Then, the precipitate of hydroxyapatite was filtered, rinsed with water and dried overnight at $105^{\circ} \mathrm{C}$. This powder was thereafter called HAP.

The deposition of ruthenium and platinum on HAP support was carried out by three methods using $\mathrm{RuCl}_{3}$ and $\mathrm{K}_{2} \mathrm{PtCl}_{4}$ as metal precursors (Aldrich, p.a. grade): Incipient wetness impregnation (IWI), cationic exchange (CEX), and excess liquid phase impregnation (LIM) [26]. IWI preparation was performed with both ruthenium and platinum (Table 1 ), because this method is simple and generally efficient for the deposition of well-dispersed metal particles for catalytic application. An aqueous solution of metal precursor was added drop-by-drop to HAP support in order to wet perfectly the powder without excess of the liquid phase. The concentration of the metals was calculated to reach the desired metals contents in the final solids. The mixture was dried at room temperature until the complete elimination of water (checked by infra-red measurement). CEX method was used for the preparation of ruthenium according to previous works, wherein ruthenium particle in the range of $3.0-5.5 \mathrm{~nm}$ were obtained [27,28]. HAP powder was added to a diluted aqueous solution of $\mathrm{RuCl}_{3}$ at room temperature under stirring $(500 \mathrm{rpm})$ for $4 \mathrm{~h}$. Then the suspension was filtered using $0.45 \mu \mathrm{m}$ filter-paper, and the solid was dried at room temperature up to the complete removal of residual water. LIM preparation was used for the deposition of platinum. This method was previously found as the most efficient for the dispersion of $\mathrm{Pt}$ on $\mathrm{TiO}_{2}$ support [26]. HAP support was added into an aqueous solution of $\mathrm{K}_{2} \mathrm{PtCl}_{4}$ under stirring for $24 \mathrm{~h}$ at room temperature in order to insert platinum species on the surface of the support. Then, platinum precursor was reduced by formaldehyde in $\mathrm{KOH}$ medium. The solid was recovered by filtration and dried at room temperature up to the complete elimination of residual water. For IWI and CEX methods, dried solids were calcined at $400^{\circ} \mathrm{C}$ under air atmosphere. For LIM method, the dried catalyst was directly used for catalytic test, without further thermal treatment. Table 1 summarized the prepared catalysts. 

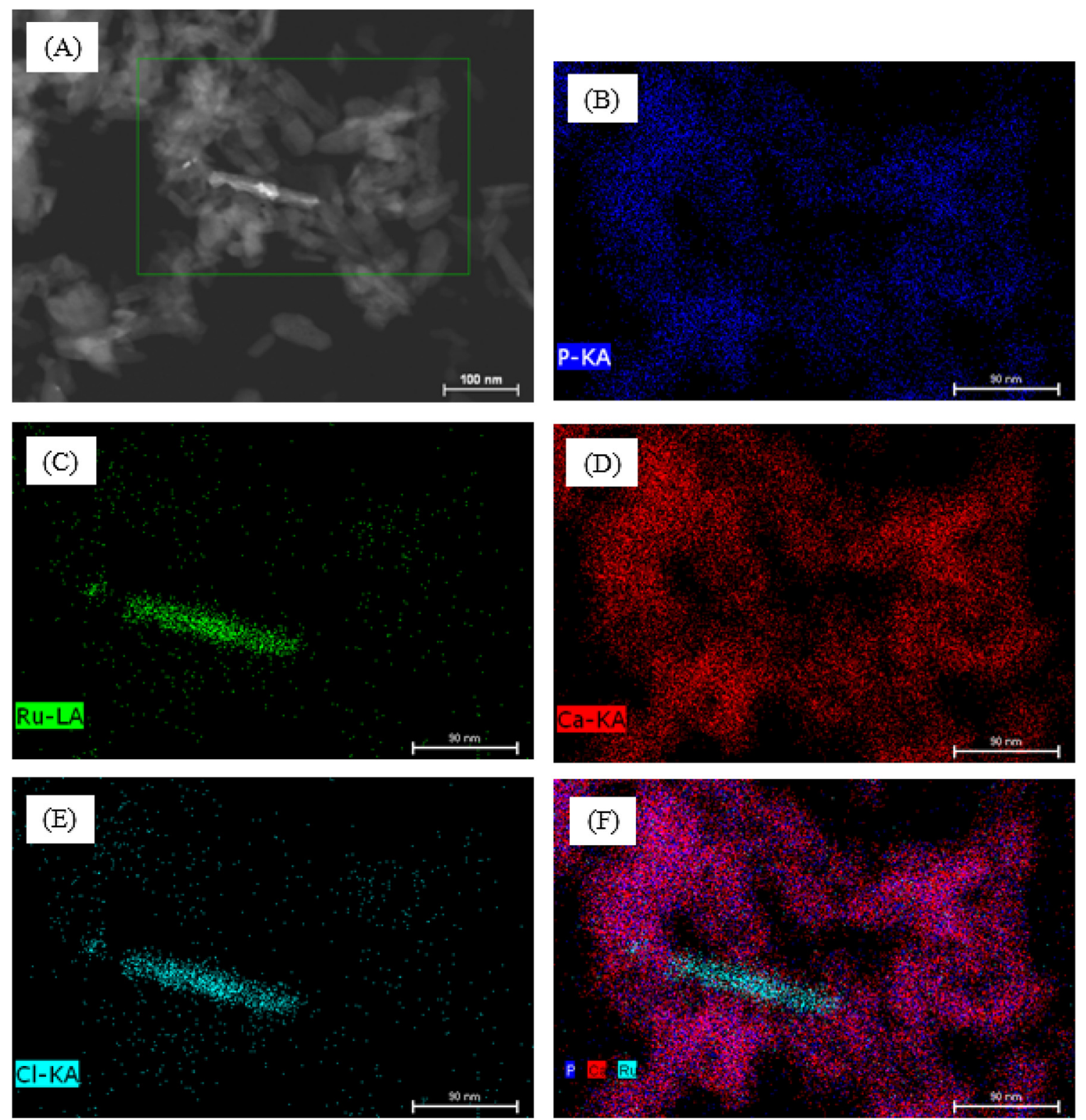

Fig. 3. Imaging of ruthenium, calcium, phosphorus, and chlorine present in Ru/HAP IWI; (A): TEM image with imaging analysis zone (green rectangle); B to E: imaging of phosphorus, ruthenium, calcium, and chlorine, respectively; (F): image treatment of phosphorus (blue), calcium (red) and ruthenium (sky-blue). (For interpretation of the references to color in this figure legend, the reader is referred to the web version of this article.).

\subsection{Catalyst characterizations}

Elemental analysis for the determination of metal loadings was carried out using ICP-AES method (HORIBA Jobin Yvon Ultima 2) after a mineralisation step. Specific surface area of solids was determined by BET method (Micrometrics Gemini Vacprep 061). Infra-red (FTIR) spectrum was recorded using a Shimadzu FTIR 8400S spectrometer. X-ray diffraction (XRD) was performed with a Phillips Panalytical X'pert Pro MPD diffractometer. The morphological and textural surface of the solid products was observed by scanning electron microscope (SEM) using a Philips XL30 ESEM apparatus (FEI Company), and by transmission electron microscope (TEM) using a FEG JEOL JEM 2100F equipped with a HAADF detector. This TEM apparatus is coupled with an EDS BRUKER which is equipped with a SDD detector (SDD of $127 \mathrm{eV}$ resolution). Carbon content due to the deposition of carbonaceous species on the used catalyst was evaluated by CHNS analyzer (CE instruments, NA2100 series).

\subsection{Catalytic test}

The reaction of methane with carbon dioxide was carried out using either a U-sharp quartz reactor or a stainless steel fixed-bed reactor. Details of these reactors will be presented later. Catalytic test was carried out using gas mixture containing $20 \mathrm{vol} . \%$ of $\mathrm{CH}_{4}$, $20 \mathrm{vol} . \%$ of $\mathrm{CO}_{2}$ and $60 \mathrm{vol} . \%$ of $\mathrm{N}_{2}$. The mixture of gas products from the outlet of the reactor were analysed by a micro-chromatograph analyser (Agilent $3000 \mu \mathrm{GC}$ ) which allowed determining the volume percentage of each gas in this mixture.

\section{Results and discussion}

\subsection{Elemental analysis}

ICP-AES was performed for the determination of Ru and Pt contents of the dried or calcined catalysts (Table 2). High deposition yields (79-90\%) were observed for both the metals by different 

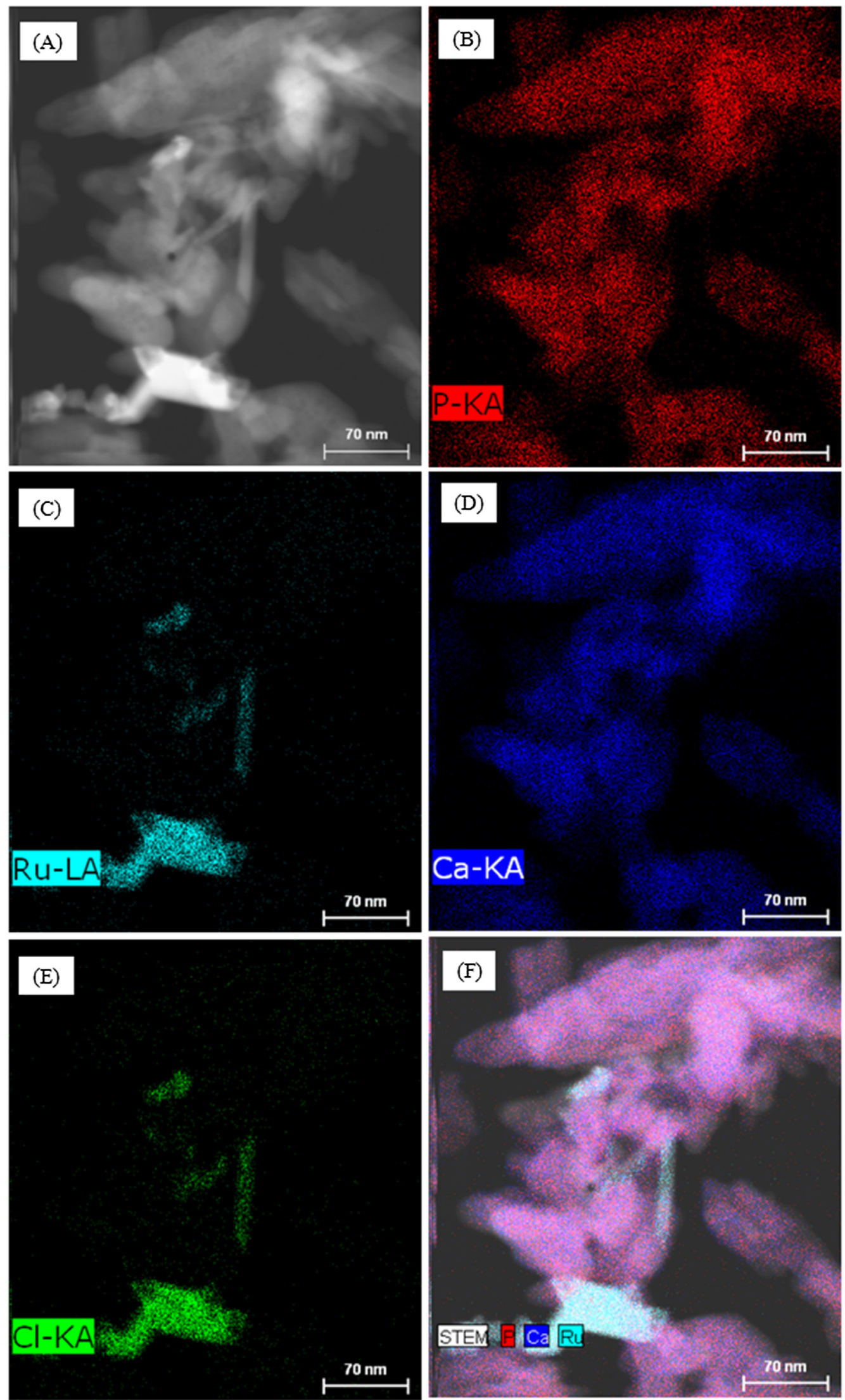

Fig. 4. Imaging of ruthenium, calcium, phosphorus, and chlorine present in Ru/HAP CEX; (A): TEM image for mapping; B to E: mapping of phosphorus, ruthenium, calcium, and chlorine, respectively; (F): image treatment of phosphorus (red), calcium (blue) and ruthenium (sky-blue). (For interpretation of the references to color in this figure legend, the reader is referred to the web version of this article.). 

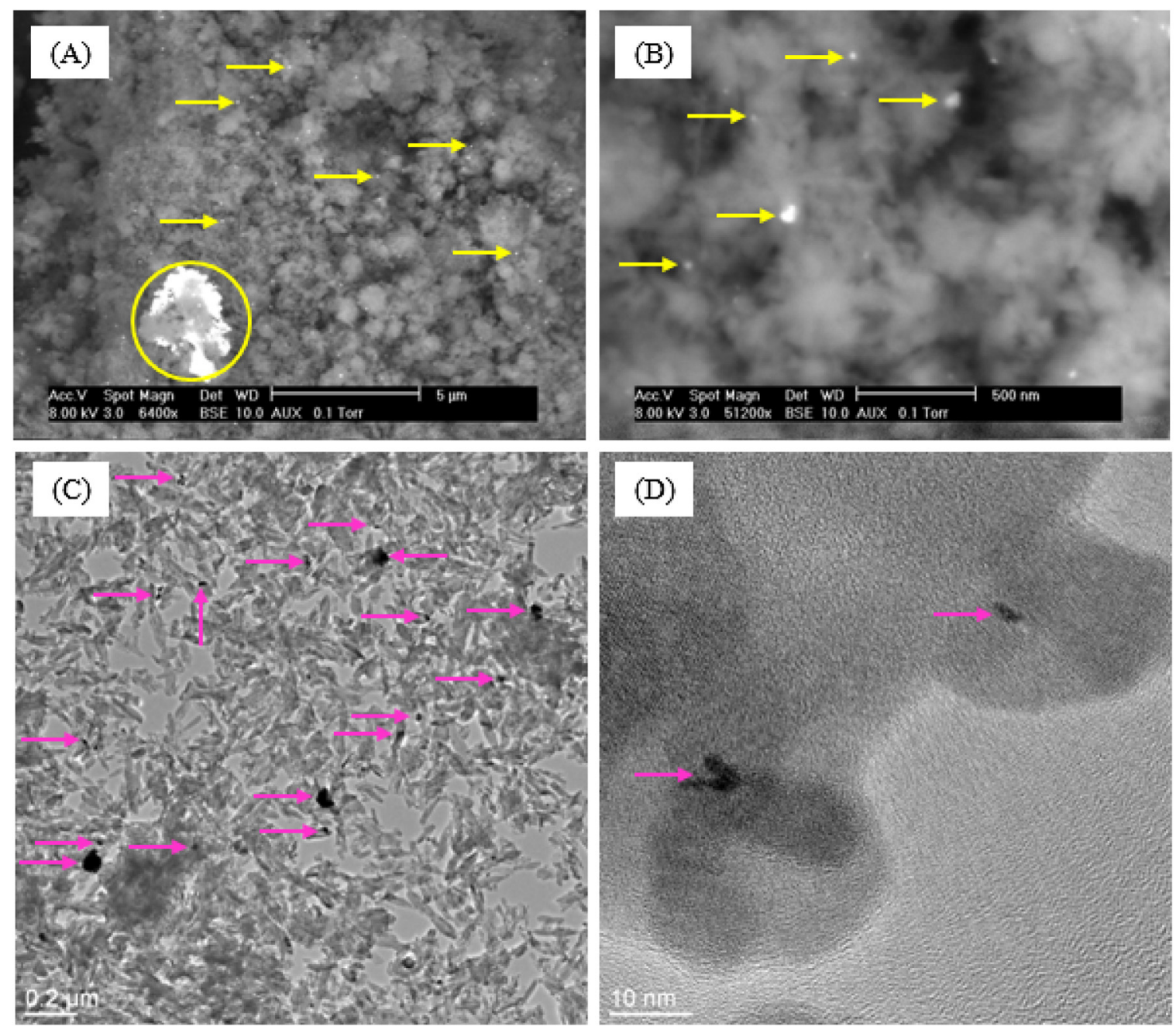

Fig. 5. SEM (A, B) and TEM (C, D) images of Pt/HAP LIM; yellow and pink arrows: Pt-based particles; yellow circle: Pt-based agglomerate. (For interpretation of the references to colour in this figure legend, the reader is referred to the web version of this article.)

Table 2

Ruthenium and platinum contents determined by ICP-AES analysis.

\begin{tabular}{lll}
\hline Catalyst & Pt or Ru (wt.\%), ICP-AES & Pt or Ru (wt.\%), theoretical value \\
\hline Pt/HAP IWI & 0.73 & 0.92 \\
Pt/HAP LIM & 0.80 & 0.92 \\
Ru/HAP IWI & 0.66 & 0.80 \\
Ru/HAP CEX & 0.72 & 0.80 \\
\hline
\end{tabular}

Table 3

Specific surface area of the initial HAP support and of the calcined catalysts.

\begin{tabular}{ll}
\hline Catalyst & $\mathrm{S}_{\mathrm{BET}}, \mathrm{m}^{2} \mathrm{~g}^{-1}$ \\
\hline Initial HAP support & 60 \\
Pt/HAP IWI & 59 \\
Pt/HAP LIM & 60 \\
Ru/HAP IWI & 57 \\
Ru/HAP CEX & 56 \\
\hline
\end{tabular}

deposition methods. The loss was probably due to the fixation of the metals on flask walls during the preparation.

\subsection{Specific surface area $\left(S_{B E T}\right)$}

Specific surface area measurement was performed with the initial HAP support and the calcined catalysts (Table 3 ). HAP support had the specific surface area of $60 \mathrm{~m}^{2} \mathrm{~g}^{-1}$. As expected, the deposition of Ru and Pt ( $<1$ wt.\%) did not significantly modify its specific surface area.

\subsection{SEM and TEM}

Fig. 1 presents SEM and TEM images of Ru/HAP IWI, or HAP supported ruthenium catalyst which was prepared by IWI method and calcined at $400^{\circ} \mathrm{C}$. At micrometric scale (Fig. 1(A) and (B)), individual particles (yellow arrows) and agglomerates of these individual particles (yellow circle) could be observed, thanks to the difference of contrast between Ru-based compounds and the elements present in HAP support. At nanometric scale, Ru particles could be more easily observed. Their particle size varied from some $\mathrm{nm}$ to hundreds of nm (pink arrows, Fig. 1(D)). Ru particles did not have the expected spherical shape. On the other hand, irregular shape and rod shape were usually observed. Well-defined particles such as rod shape are generally formed by crystalline growth in solution with the presence of surfactant. In our case, no additional surfactant was used. So, understanding the formation of these well-defined Ru particles still needs scrutiny.

SEM and TEM images of Ru/HAP CEX are presented in Fig. 2. The results were similar compared to those in Fig. 1 for Ru/HAP IWI, with the formation of both individual Ru particles and agglomerates of these individual particles (SEM images, Fig. 2(A) and (B)). At 

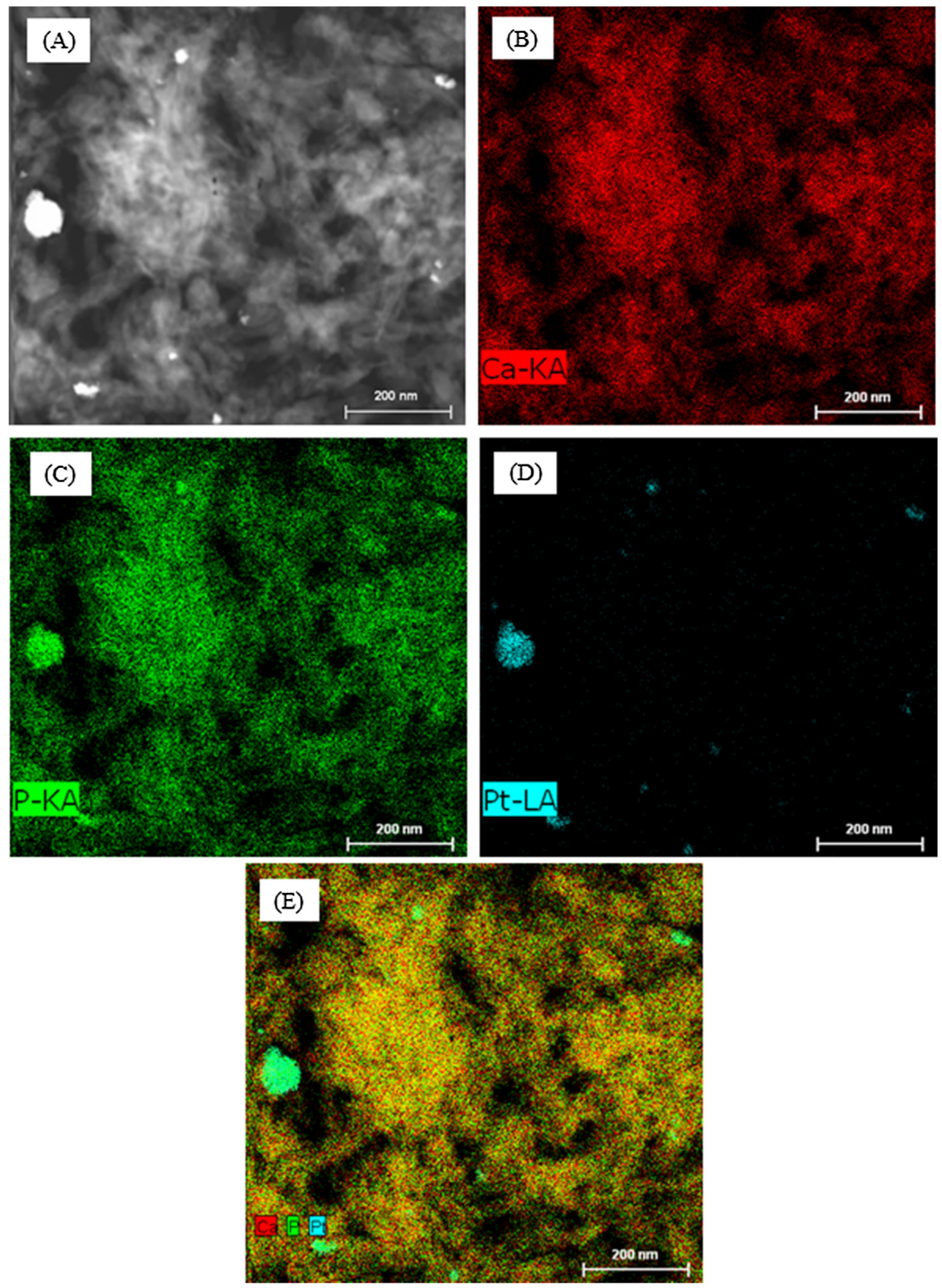

Fig. 6. Imaging of platinum, calcium, and phosphorus present in Pt/HAP LIM; (A): TEM image for mapping; B to D: mapping of calcium, phosphorus, and platinum, respectively; (E): image treatment of calcium (red), phosphorus (green) and platinum (turquoise). (For interpretation of the references to color in this figure legend, the reader is referred to the web version of this article.)

nanometric scale, Ru-based particles of irregular shape or rod shape were also observed. The formation of Ru-based particles indicates that crystallization or agglomeration of Ru-based compounds took place when HAP particles were set in contact with $\mathrm{RuCl}_{3}$ solution, and the expected cationic exchange between $\mathrm{Ru}^{3+}$ and $\mathrm{Ca}^{2+}$ did not happen or only partially occurred.

In contact with chloride anions, hydroxyl groups of apatitic structure can be partially replaced by chloride anions to form 

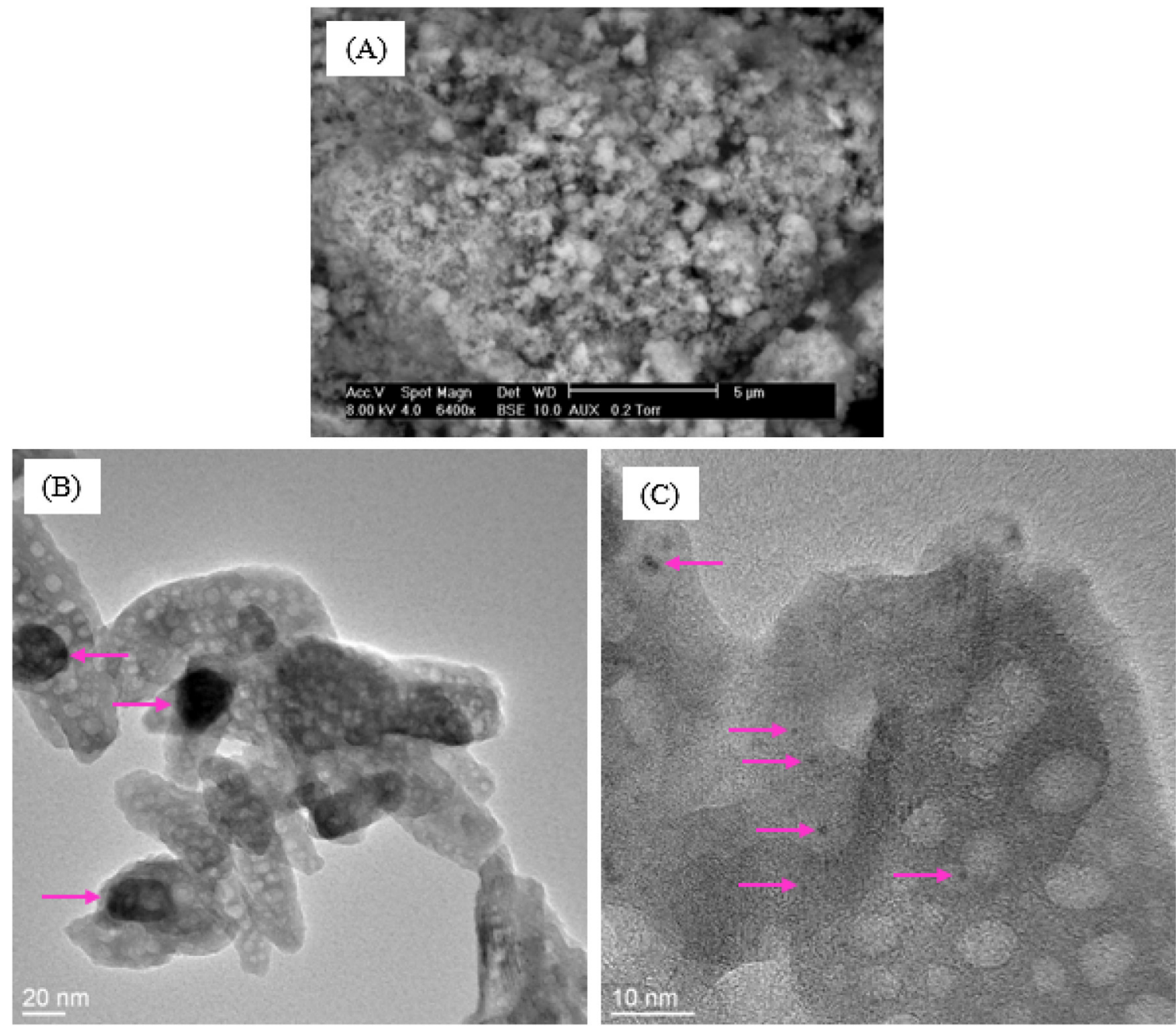

Fig. 7. SEM (A) and TEM (B, C) images of Pt/HAP IWI; pink arrows: Pt-based particles. (For interpretation of the references to color in this figure legend, the reader is referred to the web version of this article.)

chloroapatite: $\mathrm{Ca}_{10}\left(\mathrm{PO}_{4}\right)_{6}\left(\mathrm{OH}_{2-\mathrm{x}} \mathrm{Cl}_{\mathrm{x}}\right)_{2}$. To highlight the presence of chloride on the surface of HAP particles, imaging of the main elements present in HAP supported Ru catalysts was performed. Figs. 3 shows the results obtained with Ru/HAP IWI. The formation of a Ru-based rod on the surface of HAP support could be clearly observed. Chlorine seemed to be mostly associated with ruthenium. This result suggests that anionic exchange between chloride $\left(\mathrm{Cl}^{-}\right)$ and hydroxyl $\left(\mathrm{OH}^{-}\right)$anions might also take place but the sensibility of the EDX analysis was not enough for the detection of chlorine resulting from this exchange. Further analysis such as secondary ion mass spectrometry (SIMS) may be useful to highlight this anionic exchange. Also, the calcination of the catalyst at $400^{\circ} \mathrm{C}$ under air atmosphere did not allow the complete removal of chlorine from the catalytic solids.

Fig. 4 shows imaging of chemical elements present in $\mathrm{Ru} / \mathrm{HAP}$ CEX. Rod and irregular Ru-based particles on the surface of HAP support could be observed. As observed previously for $\mathrm{Ru} / \mathrm{HAP}$ IWI, Fig. 4 highlighted also the association of chlorine with ruthenium. As communicated above, ionic exchange between ruthenium species and calcium species, and between chloride and hydroxyl groups seemed to not happen.

Fig. 5 shows SEM and TEM images of Pt supported HAP catalyst, prepared by excess liquid phase impregnation (Pt/HAP LIM). Pt-based particles and agglomerates were observed either at micrometric (Fig. 5 (A)) or nanometric (Fig. 5(B), (C) and (D)) scale. The size of Pt-based particles varied from some $\mathrm{nm}$ to hundreds of $\mathrm{nm}$. Imaging analysis confirmed the presence of platinum particles at nanoscale (Fig. 6).

SEM and TEM images of Pt/HAP IWI are presented in Fig. 7. In contrast with previous catalysts, Pt-based particles of this catalyst could not be visible by SEM analysis suggesting the absence of particles or agglomerates at micrometric scale (Fig. 7(A)). At higher magnifications (Fig. 7(B) and (C)), TEM analysis highlighted the formation of Pt particles with particle size varying from less than $1 \mathrm{~nm}$ up to about $25 \mathrm{~nm}$ (pink arrows).

\section{4. $T G$}

The results of TG analysis of the initial HAP support, and the catalysts after calcinations are presented in Fig. 8. HAP support had different weight losses in the temperature range investigated, which correspond to the removal of surface moisture (around $100^{\circ} \mathrm{C}$ ), to the dehydration of hydrogenophoshate groups, and to the continuous dehydration of hydroxyl groups in the apatitic structure of HAP [29,30]. For Ru and Pt supported catalysts, the dehydration was less important up to $370^{\circ} \mathrm{C}$, because they were already calcined at $400^{\circ} \mathrm{C}$. Above $370^{\circ} \mathrm{C}$, they had the similar behavior compared to the initial HAP support. 


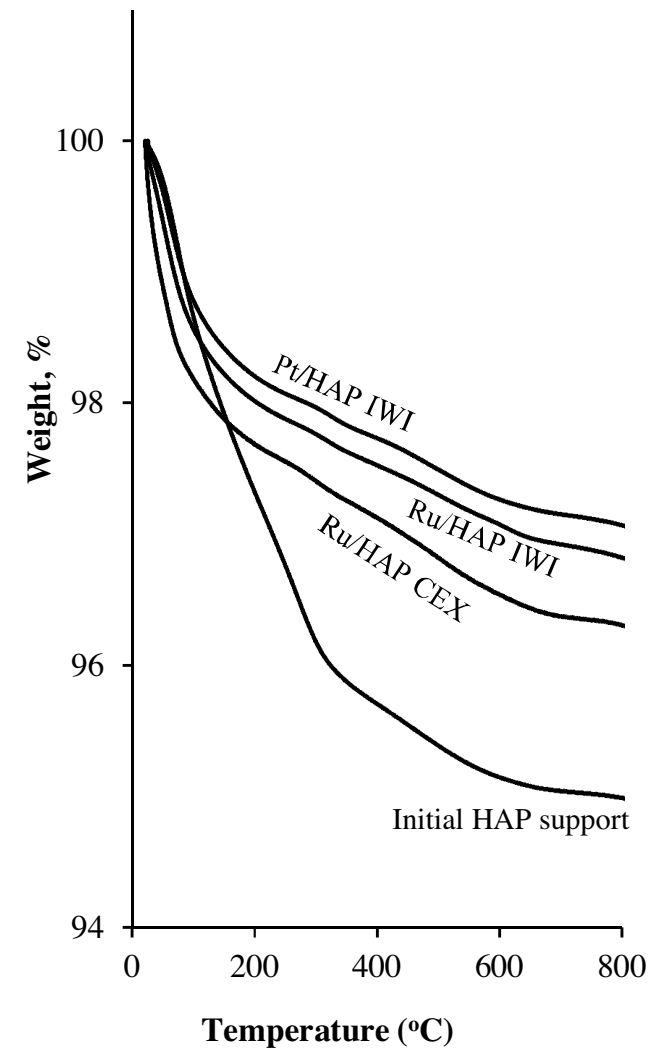

Fig. 8. TG analysis of the initial HAP support and different catalysts.

\subsection{FTIR and $X R D$}

FTIR spectra of the initial HAP support and the calcined catalysts can be found in Fig. 9. Characteristic peaks of phosphate (1076, $1038,960,603$, and $\left.559 \mathrm{~cm}^{-1}\right)$ and hydroxyl $\left(633 \mathrm{~cm}^{-1}\right)$ groups were found for HAP support [31]. As expected, FTIR spectra of the calcined Ru and Pt catalysts did not have any significant difference compared to that of HAP support.

Fig. 10 shows XRD patterns of the initial HAP support and the calcined catalysts. HAP showed low crystallinity, which is generally observed for hydroxyapatite synthesized at moderate temperature $\left(80^{\circ} \mathrm{C}\right)$. For the calcined Ru and Pt catalysts, the calcination at $400^{\circ} \mathrm{C}$ increased the crystallinity of HAP support. No crystalline phase of Ru- and Pt-based component was observed, because of their low contents in the prepared catalysts ( $<1 \mathrm{wt} . \%)$. According to the results of TEM-EDS analysis, either XRD or FTIR analyses did not reveal the presence of chloroapatite in the final prepared catalysts.

\subsection{Comparative catalytic study}

The first catalytic tests for comparing various catalysts prepared in this work were performed in a U-shape quartz reactor (Fig. 11). In the literature, the use of this reactor configuration is largely reported for bi-phasic gas-solid catalytic test. At laboratory scale, most work related to the transformation of methane and carbon dioxide into syngas was carried out with the U-shape quartz reactor $[6,8,10,12,14-16,18,20,24,32]$. For a given catalytic test, $500 \mathrm{mg}$ of catalyst was introduced into the reactor. Then, it was heated by a vertical furnace to $400^{\circ} \mathrm{C}$ at the rate of $20^{\circ} \mathrm{C} \mathrm{min}^{-1}$ under $\mathrm{N}_{2}$ flux $\left(70 \mathrm{~N} \mathrm{~mL} \mathrm{~min}^{-1}\right)$. At this temperature, the reaction was started by feeding the reactor with the mixture of gas reactants (20 vol.\% of $\mathrm{CH}_{4}, 20 \mathrm{vol}$ \% of $\mathrm{CO}_{2}$ and $60 \mathrm{vol} . \%$ of $\mathrm{N}_{2}$ ) at the flow rate of $70 \mathrm{~N} \mathrm{~mL} \mathrm{~min}{ }^{-1}$. The reaction was kept at this temperature for $1 \mathrm{~h}$ and gas product of the reaction was analyzed by an Agilent $3000 \mu$ -

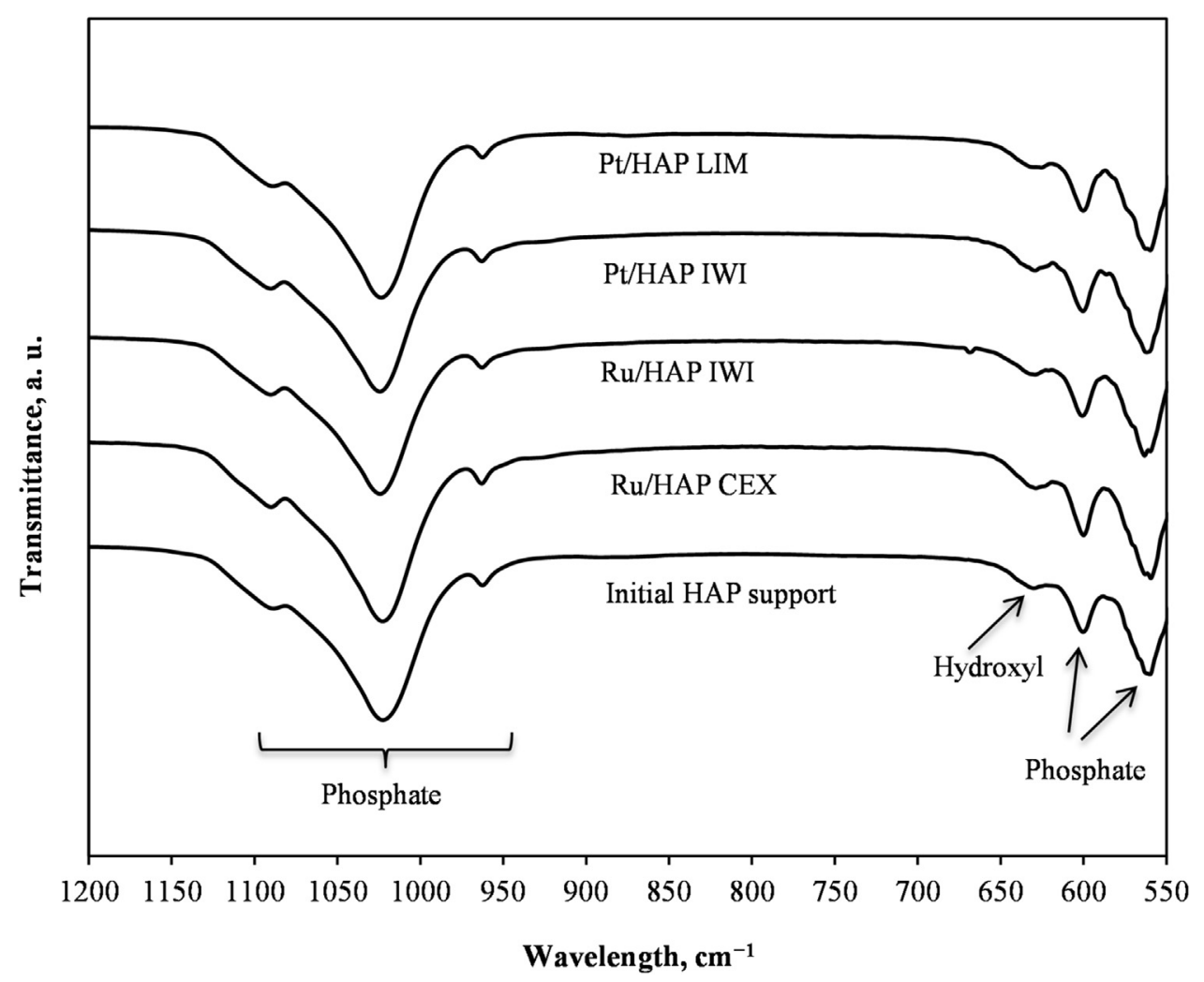

Fig. 9. FTIR spectra of the initial HAP support and the prepared Ru- and Pt-based catalysts. 


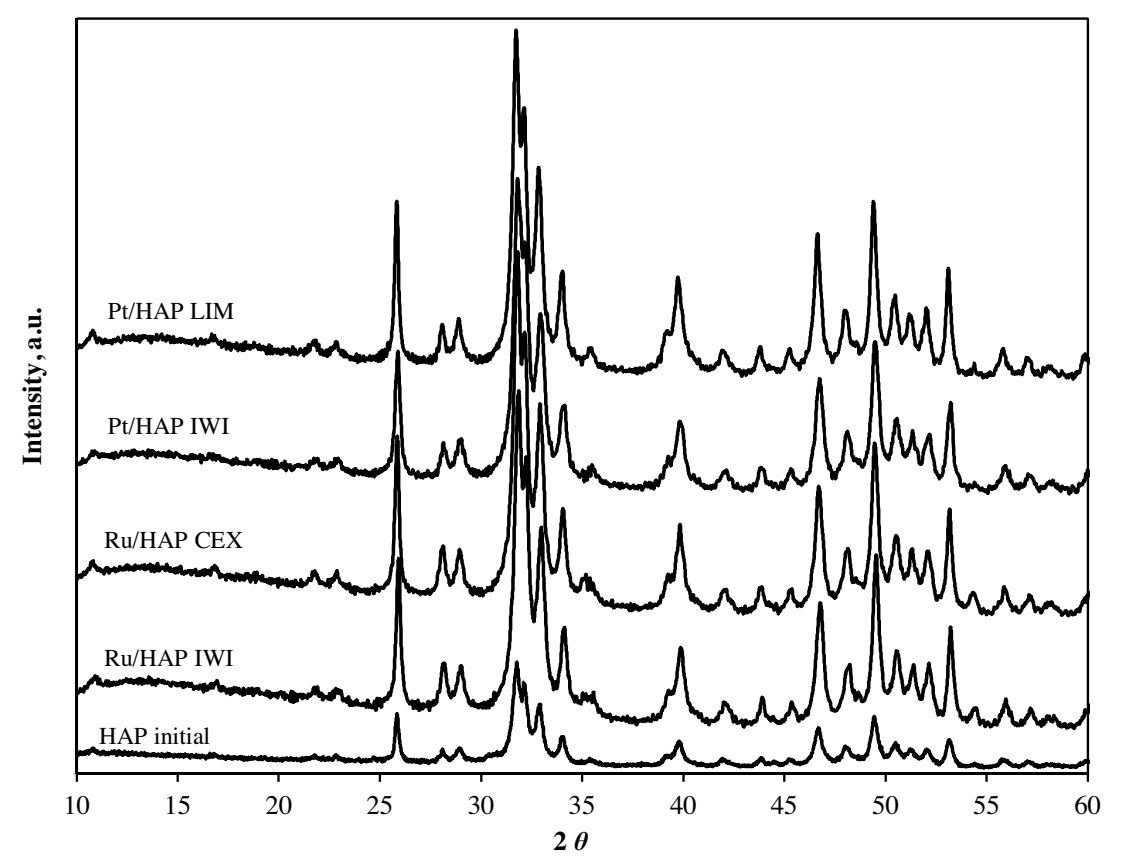

Fig. 10. XRD patterns of the initial HAP support and the prepared Ru- and Pt-based catalysts.

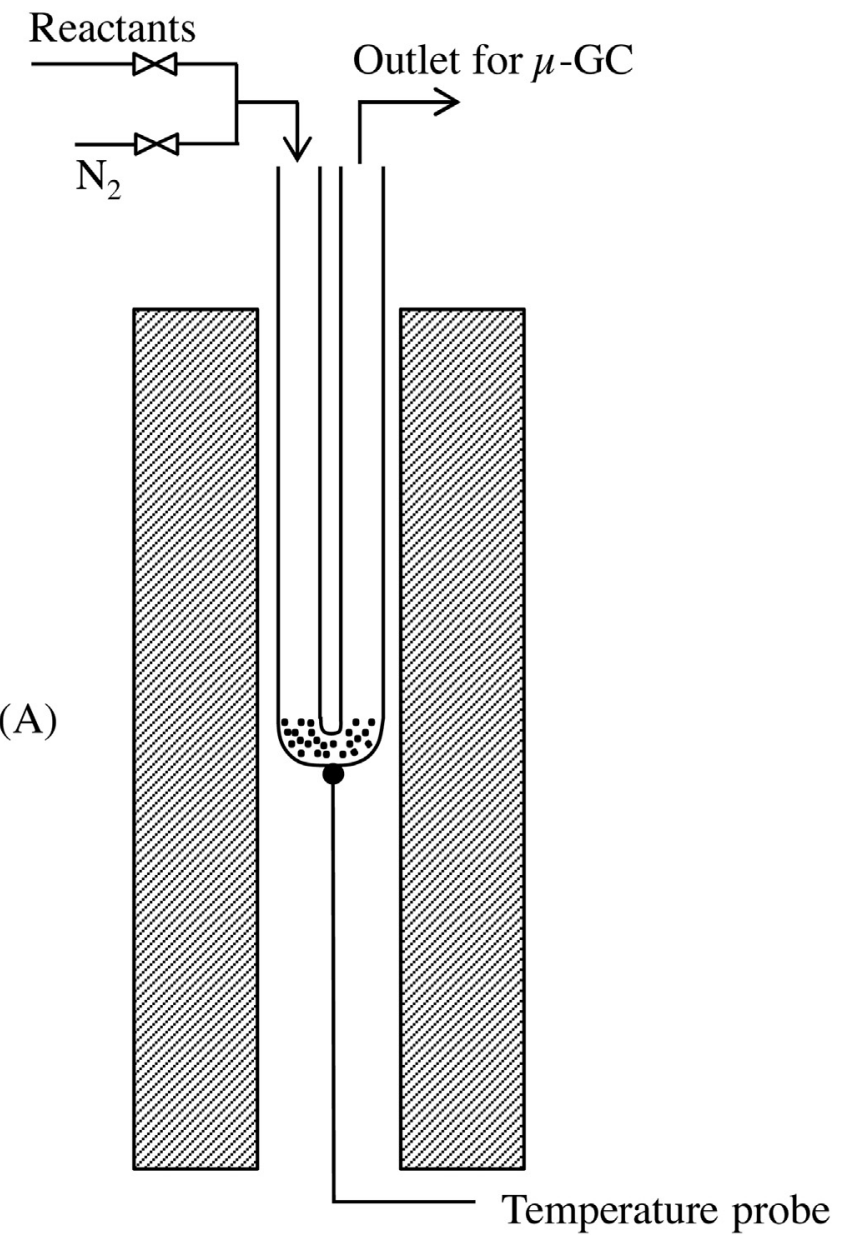

Fig. 11. Illustration of the U-shape quartz reactor used in this study; Reactants: mixture of 20 vol.\% of $\mathrm{CH}_{4}, 20$ vol.\% of $\mathrm{CO}_{2}$ and 60 vol.\% of $\mathrm{N}_{2}$.
GC. Then, the reaction temperature was changed to $500^{\circ} \mathrm{C}$ at the heating rate of $20^{\circ} \mathrm{Cmin}^{-1}$, and was kept at this temperature for $1 \mathrm{~h}$, under the flux of reactants. Gas product of the reaction was also analyzed by $\mu$-GC. This procedure was repeated for 600 and $700^{\circ} \mathrm{C}$. Catalytic tests using successively-increased temperature programs were already reported by Baktash et al. [33].

The initial HAP support had negligible catalytic activity under the reaction conditions used (result not showed). For Ru and Pt catalysts summarized in Table 1, the results obtained are shown in Fig. 12 for the evolution of the concentration of $\mathrm{CH}_{4}$ and $\mathrm{CO}_{2}$. For all four catalysts, the concentration of $\mathrm{CH}_{4}$ was always slightly higher than that of $\mathrm{CO}_{2}$, in the final gas product mixture. It may be due to the reverse water-gas-shift reaction, where $\mathrm{CO}_{2}$ reacts with $\mathrm{H}_{2}$ to form $\mathrm{CO}$ and $\mathrm{H}_{2} \mathrm{O}$, as shown in Eq. (4) [19]. Ru catalysts were found active within the temperature range investigated $\left(400-700^{\circ} \mathrm{C}\right)$. But the deactivation seemed to be important. The reactivity of Ru/HAP IWI slowed down strongly within the first three hours of time-onstream when the reaction was kept at $500-700^{\circ} \mathrm{C}$. For Ru/HAP CEX, it partially lost its reactivity between 600 and $700{ }^{\circ} \mathrm{C}$ (decrease of $\mathrm{H}_{2}$ and $\mathrm{CO}$ production at $700^{\circ} \mathrm{C}$ ). This was probably due to the formation of carbonaceous deposits on the surface of the catalysts, as illustrated in Fig. 13. Carbonaceous species covered the surface of Ru catalyst, leading to the reduction of available active sites and so causing the catalytic deactivation. This carbon deposition must be due to side reactions of the process, including the Boudouard reaction (Eq. (5)), and the methane cracking (Eq. (6)).

$$
\begin{aligned}
& \mathrm{CH}_{4}+\mathrm{CO}_{2} \rightarrow 2 \mathrm{CO}+2 \mathrm{H}_{2} \Delta \mathrm{H}^{\circ}{ }_{298}=247 \mathrm{~kJ} \mathrm{~mol}^{-1} \\
& \mathrm{CO}_{2}+\mathrm{H}_{2} \rightarrow \mathrm{CO}+\mathrm{H}_{2} \mathrm{O} \Delta \mathrm{H}^{\circ}{ }_{298}=41 \mathrm{~kJ} \mathrm{~mol}^{-1} \\
& 2 \mathrm{CO} \rightarrow \mathrm{C}+\mathrm{CO}_{2} \Delta \mathrm{H}^{\circ}{ }_{298}=-172 \mathrm{~kJ} \mathrm{~mol}^{-1} \\
& \mathrm{CH}_{4} \rightarrow \mathrm{C}+2 \mathrm{H}_{2} \Delta \mathrm{H}^{\circ}{ }_{298}=75 \mathrm{~kJ} \mathrm{~mol}^{-1}
\end{aligned}
$$

As expected, $\mathrm{CO}$ and $\mathrm{H}_{2}$ were found to be the main gas products of the reaction. No other peak was detected from the mixture of gas products of the reaction by $\mu$-GC analysis. In all cases, the concentration of $\mathrm{CO}$ was systematically higher than that of $\mathrm{H}_{2}$. As explained above, the water-gas-shift reaction must happen (Eq. (4)), taking into account the fact that the concentration of $\mathrm{CO}_{2}$ was always smaller than that of $\mathrm{CH}_{4}$ in the final gas products. 

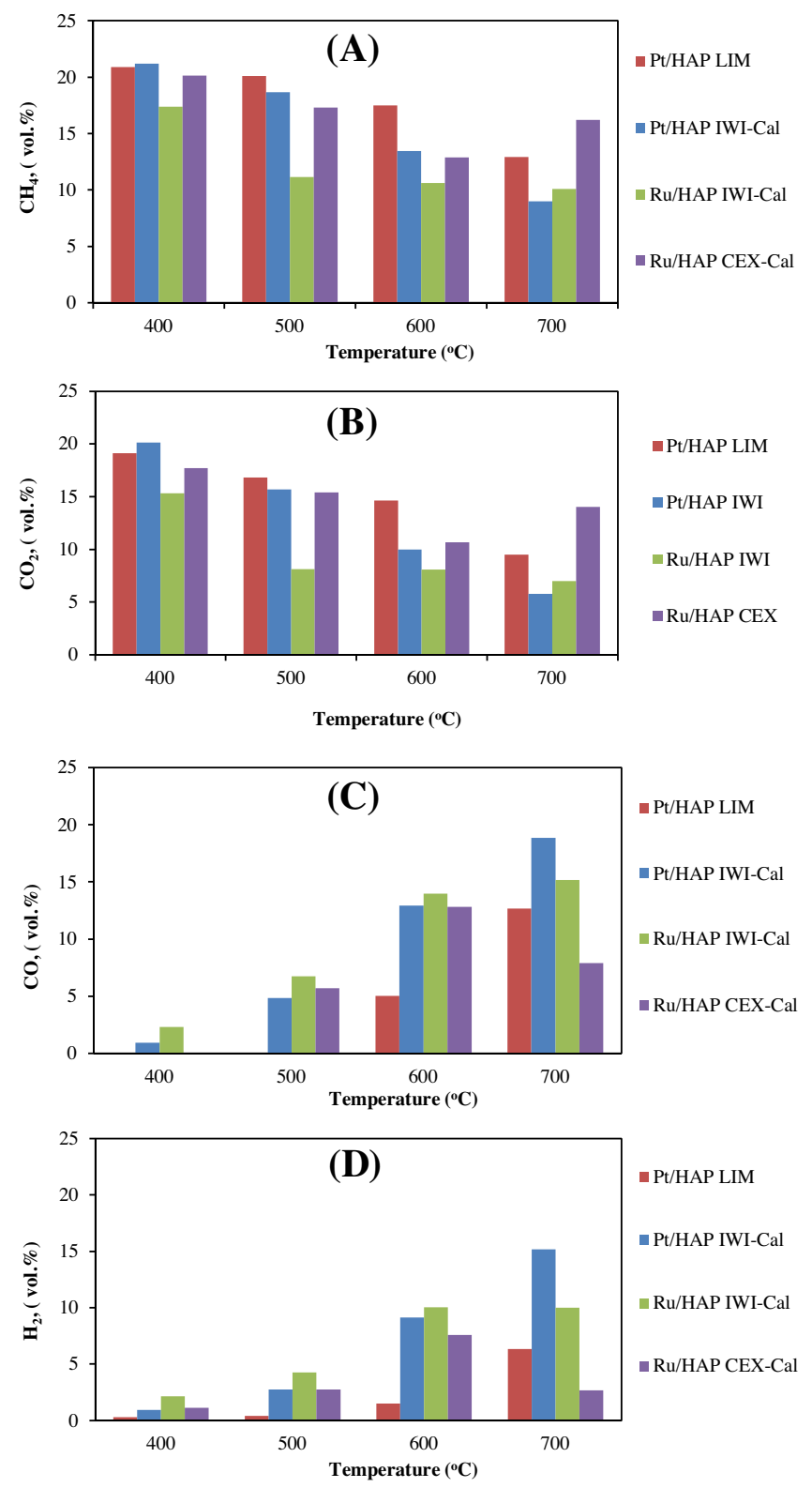

Fig. 12. Evolution of the concentration of methane (A), carbon dioxide (B), carbon monoxide (C) and hydrogen (D) in the final reaction product over Ru and Pt supported catalysts at $400-700{ }^{\circ} \mathrm{C}$ and atmospheric pressure using U-shape quartz reactor; $500 \mathrm{mg}$ of catalyst; inlet gas flow rate: $70 \mathrm{~N} \mathrm{~mL} \mathrm{~min}{ }^{-1}$ of $20 \% \mathrm{CO}_{2}-20 \% \mathrm{CH}_{4}-60 \% \mathrm{~N}_{2}$.
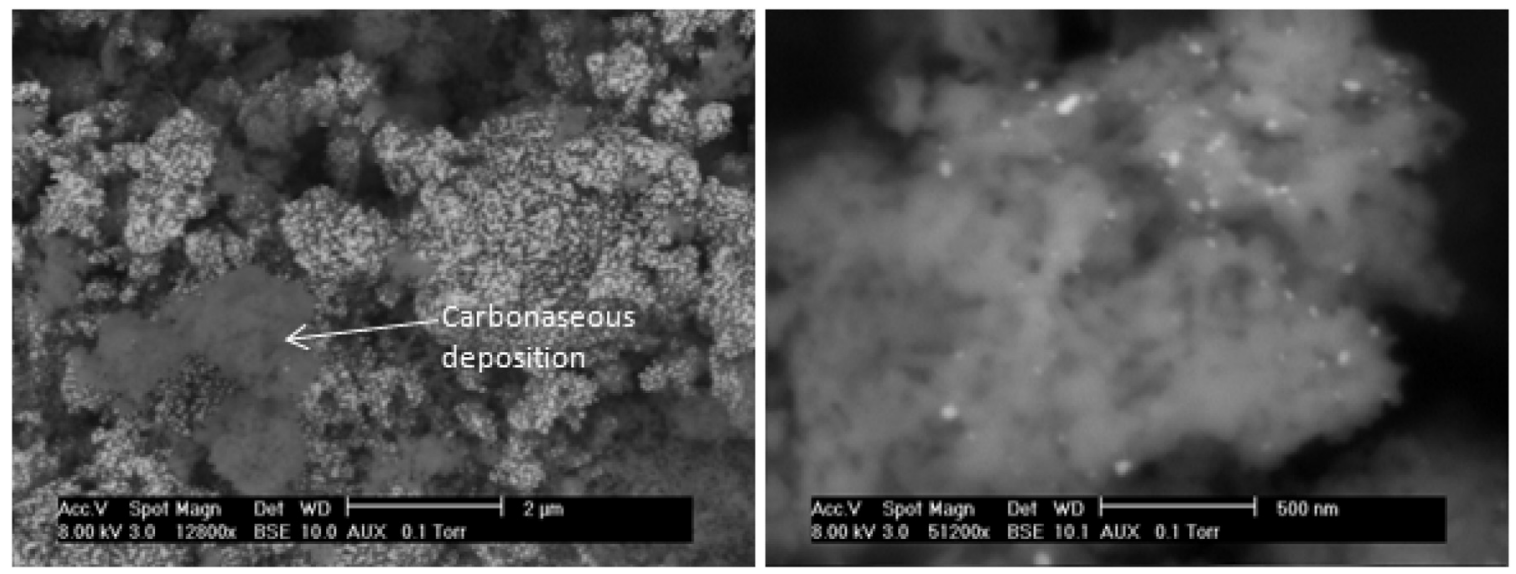

Fig. 13. Illustration of carbonaceous deposition on Ru/HAP IWI after catalytic test in the U-shape quartz reactor. 


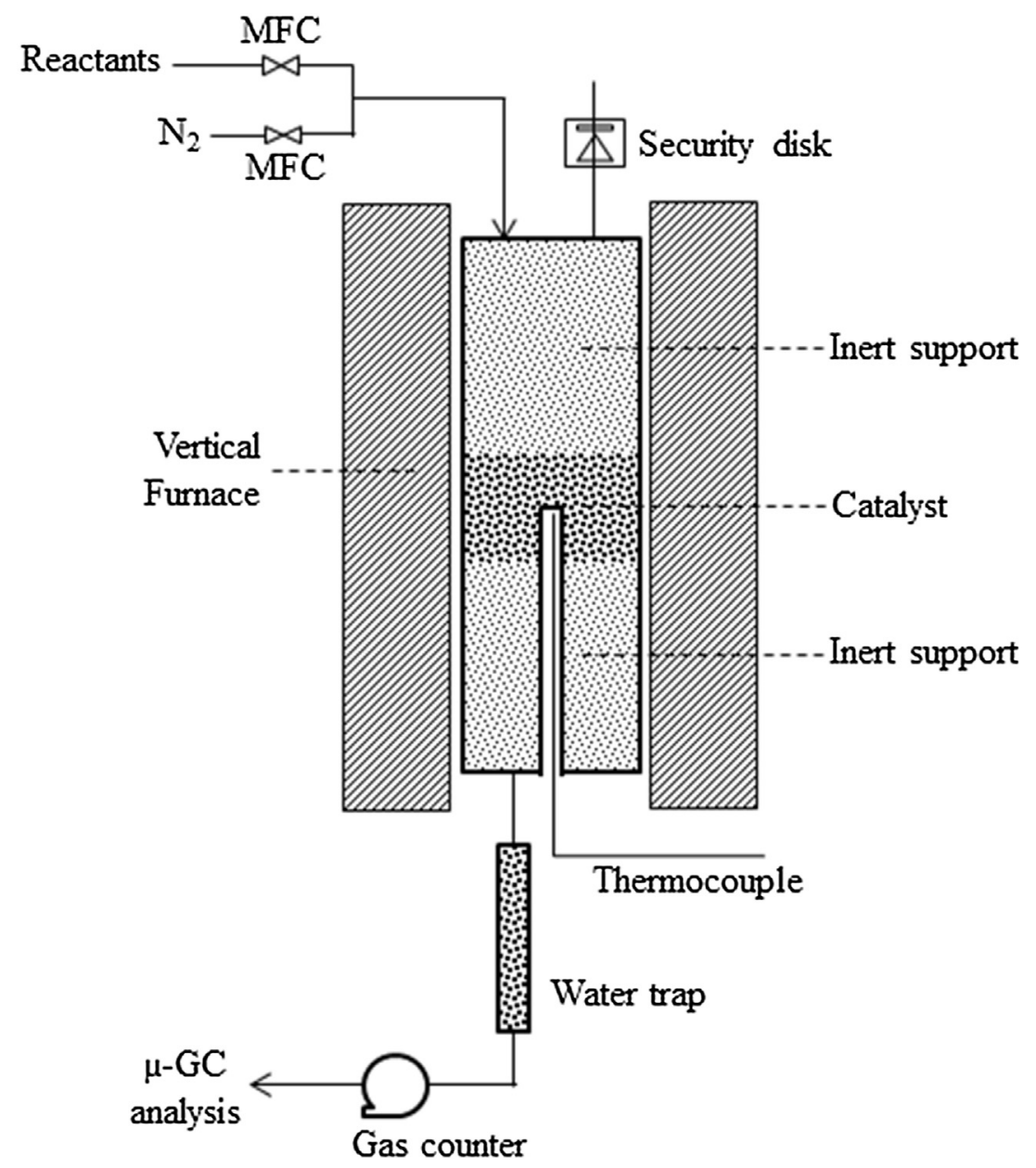

Fig. 14. Scheme of the stainless steel fixed-bed reactor. Reactants: mixture of 20 vol.\% of $\mathrm{CH}_{4}, 20 \mathrm{vol} . \%$ of $\mathrm{CO}_{2}$ and 60 vol. $\%$ of $\mathrm{N}_{2}$; $\mathrm{MCF}$ : mass flow controller; limit pressure: 30 bar; internal diameter: $8 \mathrm{~mm}$; total length of the reactor: $30 \mathrm{~cm}$; homogeneous temperature zone: $8 \mathrm{~cm}$ at the center of the reactor.

Platinum catalysts were found active in this reaction. Pt/HAP IWI was much more active than Pt/HAP LIM. This seemed to be in coherence with SEM and TEM analyses. In fact, Pt particles present in Pt/HAP IWI (Fig. 7) were more dispersed than those present in Pt/HAP LIM (Fig. 5). This means that Pt is more available when prepared by IWI method compared to LIM method. For Pt/HAP IWI, at $700{ }^{\circ} \mathrm{C}$, the concentrations of $\mathrm{CH}_{4}$ and $\mathrm{CO}_{2}$ remaining in the gas product mixture were around 6 and $9 \%$, respectively, for the reaction time of $5 \mathrm{~h}$ at this temperature.

\subsection{Isothermal test}

The U-shape quartz reactor above has advantage to be simply designed and fabricated. However, powder catalyst cannot be really immobilized under gas stream. Consequently, when gas flow rates accidentally increase, catalyst bed becomes fluidized and can get out the reactor. The risk of preferential gas passage may also be present. Thus, a stainless steel fixed-bed reactor was designed and fabricated for isothermal catalytic test. Fig. 14 shows the scheme of this reactor.

The same reactants mixture was used for the isothermal catalytic test. The catalyst bed was now fixed between two beds of inert alumina. The reaction temperature was controlled by a thermocouple, set at the center of the catalyst bed. At the outlet of the reactor, a gas counter was used for measuring the total gas flow rate. From this last one and the concentration of each gas, analyzed by $\mu$-GC, the molar flow rate of each gas at the outlet of the reactor
$\left(Q_{i}\right.$, mol h$\left.^{-1}\right)$ could be obtained. The conversion and the selectivity of the reaction were thus calculated as follows:

$X_{\mathrm{CH} 4}, \%=\frac{Q_{\mathrm{CH} 4}^{E}-Q_{\mathrm{CH} 4}^{O}}{Q_{\mathrm{CH} 4}^{E}} \times 100$

$X_{\mathrm{CO} 2}, \%=\frac{Q_{\mathrm{CO} 2}^{E}-Q_{\mathrm{CO} 2}^{O}}{Q_{\mathrm{CO} 2}^{E}} \times 100$

$\mathrm{Sel}_{\mathrm{CO}}, \%=\frac{\mathrm{Q}_{\text {Oxygen }}^{O}}{\mathrm{Q}_{\text {Oxygen }}^{T}} \times 100$

$\operatorname{Sel}_{\mathrm{H} 2}, \%=\frac{Q_{\text {Hydrogen }}^{O}}{Q_{\text {Hydrogen }}^{T}} \times 100$

where: $X_{\mathrm{CH} 4}$ and $\mathrm{X}_{\mathrm{CO} 2}$ : conversion of $\mathrm{CH}_{4}$ and $\mathrm{CO}_{2}$, respectively; $\mathrm{Q}_{\mathrm{CH} 4}^{\mathrm{E}}$ and $\mathrm{Q}_{\mathrm{CH} 4}^{\mathrm{O}}$ : molar flow rate of $\mathrm{CH}_{4}\left(\mathrm{~mol} \mathrm{~h}^{-1}\right)$ at the inlet and outlet of the reactor; $Q_{\mathrm{CO} 2}^{E}$ and $Q_{\mathrm{CO} 2}^{O}$ : molar flow rate of $\mathrm{CO}_{2}\left(\mathrm{~mol} \mathrm{~h}^{-1}\right)$ at the inlet and outlet of the reactor; $\mathrm{Sel}_{\mathrm{CO}}$ and $\mathrm{Sel}_{\mathrm{H} 2}$ : selectivity of the reaction in $\mathrm{CO}$ and $\mathrm{H}_{2}$, respectively; $Q_{\text {Oxygen }}^{E}$ and $Q_{\text {Oxygen }}^{O}$ : atomic flow rate of oxygen $\left(\mathrm{mol} \mathrm{h}^{-1}\right.$ ) at the inlet (under $\mathrm{CO}_{2}$ form) and outlet (under CO form) of the reactor; $Q_{\text {Hydrogen }}^{E}$ and $Q_{\text {Hydrogen }}^{O}$ : atomic flow rate of hydrogen $\left(\mathrm{mol} \mathrm{h}^{-1}\right)$ at the inlet (under $\mathrm{CH}_{4}$ form) and outlet (under $\mathrm{H}_{2}$ form) of the reactor.

The major problem of this catalytic process is the deactivation due to carbon deposition. This deposition is favored by decreasing reaction temperature [34]. So, the isothermal catalytic test was carried out at $700^{\circ} \mathrm{C}$. Pt/HAP IWI was selected for this test because 

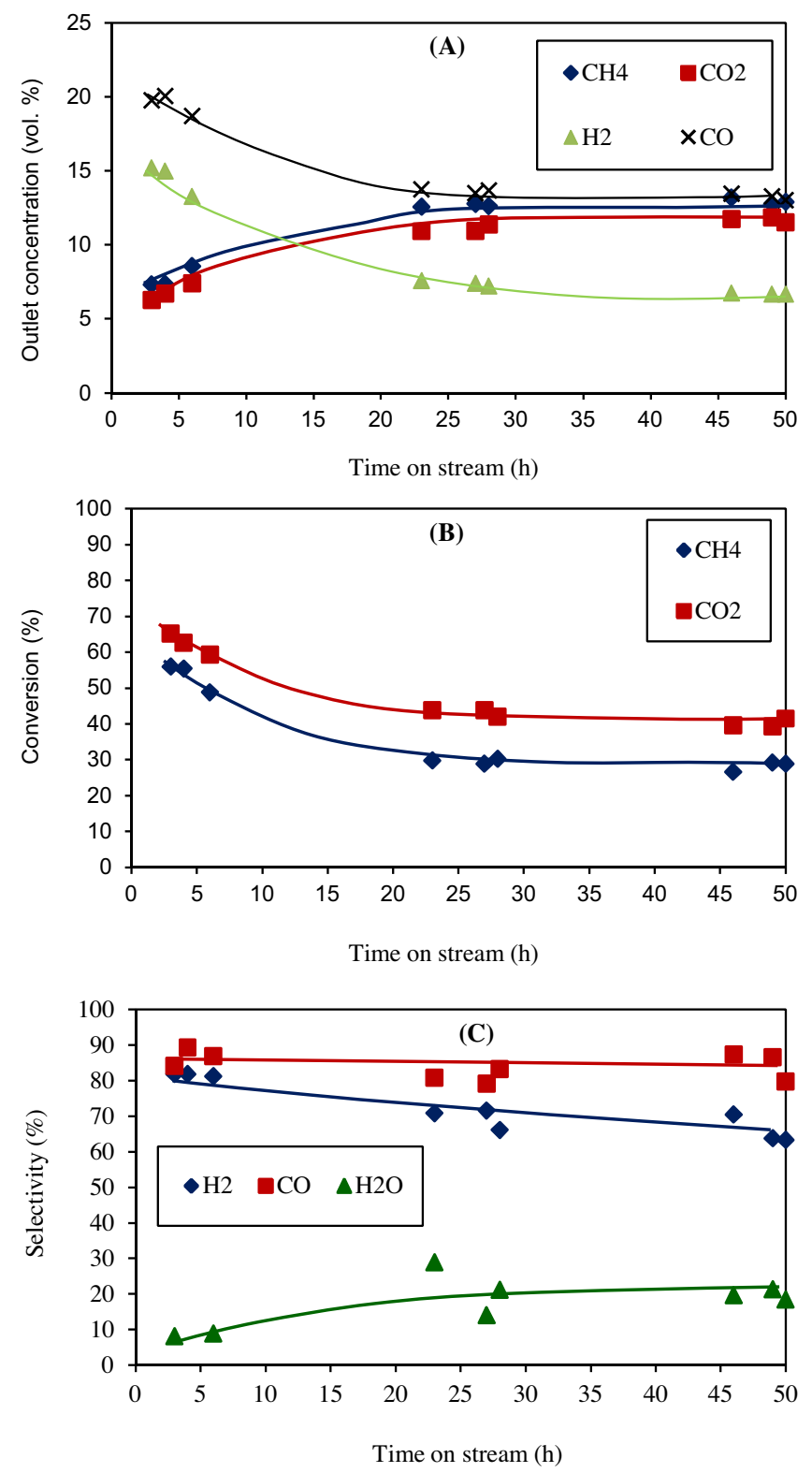

Fig. 15. Catalytic performance of $\mathrm{Pt} / \mathrm{HAP} \mathrm{IWI}$ at $700{ }^{\circ} \mathrm{C} ; 500 \mathrm{mg}$ of catalyst; inlet gas flow rate: $70 \mathrm{~N} \mathrm{~mL} \mathrm{~min}^{-1}$; (A): outlet gas composition; $(\mathrm{B})$ conversion of $\mathrm{CH}_{4}$ and $\mathrm{CO}_{2}$, and (C): selectivity in $\mathrm{H}_{2}$ and $\mathrm{CO}$ calculated from the total gas flow rate and the concentration of gas at the outlet of the reactor.

it appeared as the most performant catalyst from Fig. 12. The catalyst was heated under nitrogen $\left(70 \mathrm{~N} \mathrm{~mL} \mathrm{~min}^{-1}\right)$ up to $700^{\circ} \mathrm{C}$. At this temperature, the reactor was fed with the mixture of reactants containing 20 vol.\% of $\mathrm{CH}_{4}, 20$ vol.\% of $\mathrm{CO}_{2}$ and 60 vol.\% of $\mathrm{N}_{2}$ $\left(70 \mathrm{~N} \mathrm{~mL} \mathrm{~min}{ }^{-1}\right)$ for starting the catalytic test.

Fig. 15(A) simply reports the composition of gas at the outlet of the reactor obtained by $\mu$-GC. These results confirmed those obtained with the U-shape quartz reactor (Fig. 12 for Pt/HAP IWI catalyst at $700^{\circ} \mathrm{C}$ ). The remaining concentration of $\mathrm{CH}_{4}$ and $\mathrm{CO}_{2}$ at the outlet of the reactor was about 7-9 and 6-7\% within the first hours of reaction, respectively. These correspond to the conversion of $\mathrm{CH}_{4}$ and $\mathrm{CO}_{2}$ close to 50 and $67 \%$, respectively (Fig. 15(B)). The catalyst reached the stability after only the first ten hours of time-on-stream. The initial deactivation could be attributed to the carbonaceous deposition, as shown by SEM analysis (Fig. 16). Crystallites of HAP support were slightly covered by amorphous carbonaceous species. But Pt particles, with high contrast, could be observed (yellow arrows, Fig. 16), signifying that they could still be accessible for the catalytic reaction. This last one explains the stability of the catalyst after the first ten hours of time-on-stream.

Along the reaction, the conversion of $\mathrm{CO}_{2}$ was higher compared to that of $\mathrm{CH}_{4}$. It has been usually reported in the literature, as recently reviewed by Usman et al. [35], and could be explained by the reverse water-gas-shift reaction (Eq. (4)). This reaction is generally favorable at the temperature range of $400-800{ }^{\circ} \mathrm{C}$ [31]. Table 4 shows some results reported in the literature on the conversion of $\mathrm{CH}_{4}$ and $\mathrm{CO}_{2}$ at $700^{\circ} \mathrm{C}$ and ambient pressure over noble metalbased catalysts. Under the similar reaction conditions, the catalytic activity of platinum supported on HAP support (this work) could be compared with that of noble metal-based catalysts, prepared on other supports. According to TEM results in Fig. 7, the catalytic performance of our Pt/HAP IWI can still be improved by limiting the formation of large Pt particles.

The selectivity reached around $87 \%$ into CO and around $70-80 \%$ into $\mathrm{H}_{2}$ (Fig. 15(C)). This confirms the results obtained with the Ushape quartz reactor above (Fig. 12(C) and (D) for Pt/HAP IWI at 

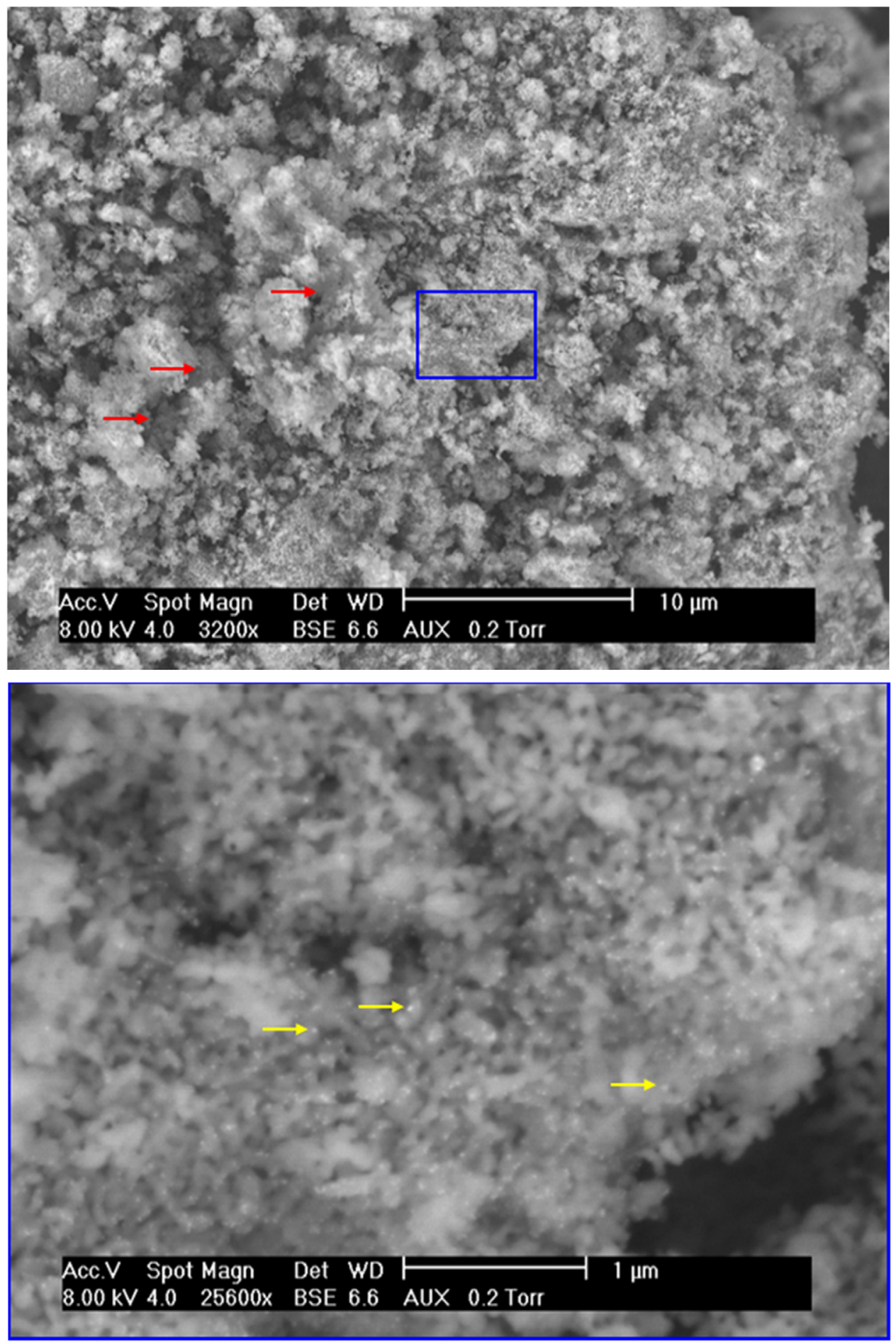

Fig. 16. Example of SEM image of Pt/HAP IWI after $7 \mathrm{~h}$ of catalytic test.

$\left.700^{\circ} \mathrm{C}\right)$. Previously, we supposed that side reactions took place, in particular the water-gas-shift reaction (Eq. (4)). Fig. 15(C) enhances this hypothesis, wherein the selectivity in $\mathrm{H}_{2}$ was smaller than the selectivity in $\mathrm{CO}$, and the conversion of $\mathrm{CO}_{2}$ was higher than that of $\mathrm{CH}_{4}$. Using a water trap at the outlet of reactor (Fig. 14), which contains fine particles of silica-gel, water was well identified and quantified as by-product of the reaction. The increase of water selectivity with the decrease of hydrogen selectivity confirmed that water-gas-shift took place. Note that water analysis has never been reported for this process. The formation of water was discussed by
Pintar's research team $[10,40,41]$ but any details were given on how it has been done.

From the flow rate and the composition of the outlet gas measured along the reaction, the matter balance for all the elements of the reaction could be established (Fig. 17). Hydrogen balance was done with water, hydrogen and methane. Oxygen balance was performed with water, carbon monoxide and carbon dioxide. Carbon balance was obtained with methane, carbon monoxide and carbon dioxide. Note that coke deposition was not included into the carbon balance because it could not be correctly measured during 
Table 4

Reactivity of noble metal-based catalysts at $700^{\circ} \mathrm{C}$ and ambient pressure for the conversion of methane and carbon dioxide into syngas.

\begin{tabular}{|c|c|c|c|c|c|c|c|c|}
\hline $\begin{array}{l}\text { Metal and its } \\
\text { content (wt.\%) }\end{array}$ & Support & $\begin{array}{l}\text { Catalyst weight, } \\
\text { mg }\end{array}$ & $\begin{array}{l}\text { Inlet gas } \\
\text { composition, vol.\% }\end{array}$ & 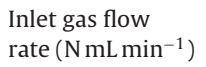 & $\mathrm{CH}_{4}$ conv., \% & $\mathrm{CO}_{2}$ conv., $\%$ & Time-on-stream, h & Refs. \\
\hline \multirow[t]{2}{*}{$1 \% \mathrm{Pd}$} & $\mathrm{Al}_{2} \mathrm{O}_{3}$ & 100 & $\begin{array}{l}25 \% \mathrm{CH}_{4}, 25 \% \mathrm{CO}_{2} \\
\text { diluted in } \mathrm{He}\end{array}$ & 4 & $\approx 59$ & $\approx 52$ & 3 & [36] \\
\hline & & & & & $\approx 44$ & $\approx 37$ & 6 & \\
\hline \multirow[t]{3}{*}{$1 \% \mathrm{Pt}$} & $\mathrm{MgO}-\mathrm{Al}_{2} \mathrm{O}_{3}$ & 50 & $\begin{array}{l}33 \% \mathrm{CH}_{4}, 33 \% \mathrm{CO}_{2} \\
\text { diluted in } \mathrm{N}_{2}\end{array}$ & $\mathrm{x}$ & 81 & 72 & 6 & [37] \\
\hline & $\mathrm{ZrO}_{2}-\mathrm{Al}_{2} \mathrm{O}_{3}$ & & & & 86 & 70 & & \\
\hline & $\mathrm{CeO}_{2}-\mathrm{Al}_{2} \mathrm{O}_{3}$ & & & & 90 & 78 & & \\
\hline \multirow[t]{2}{*}{$1 \% \mathrm{Ru}$} & $\mathrm{ZrO}_{2}-\mathrm{Al}_{2} \mathrm{O}_{3}$ & & & & 50 & 85 & & \\
\hline & $\mathrm{MgO}-\mathrm{Al}_{2} \mathrm{O}_{3}$ & & & & 50 & 37 & & \\
\hline \multirow[t]{2}{*}{$1 \% \mathrm{Pt}$} & $\mathrm{La}_{2} \mathrm{O}_{3}$ & 500 & $\begin{array}{l}10 \% \mathrm{CH}_{4}, 10 \% \mathrm{CO}_{2} \\
\text { diluted in } \mathrm{Ar}\end{array}$ & 83 & $\approx 78$ & $\mathrm{x}$ & $\mathrm{x}$ & [38] \\
\hline & $\mathrm{Al}_{2} \mathrm{O}_{3}$ & & & & $\approx 86$ & & & \\
\hline \multirow[t]{2}{*}{$0.5 \% \mathrm{Rh}$} & $\mathrm{La}_{2} \mathrm{O}_{3}$ & & & & $\approx 90$ & & & \\
\hline & $\mathrm{Al}_{2} \mathrm{O}_{3}$ & & & & $\approx 90$ & & & \\
\hline $1 \% \mathrm{Pt}$ & $\mathrm{ZrO}_{2}$ & 100 & $50 \% \mathrm{CH}_{4}, 50 \% \mathrm{CO}_{2}$ & 26 & 79 & 86 & 4 & [39] \\
\hline $0.7 \% \mathrm{Pt}$ & HAP & 500 & $\begin{array}{l}20 \% \mathrm{CH}_{4}, 20 \% \mathrm{CO}_{2} \\
\text { diluted in } \mathrm{N}_{2}\end{array}$ & 70 & 30 & 40 & 50 & This work \\
\hline
\end{tabular}
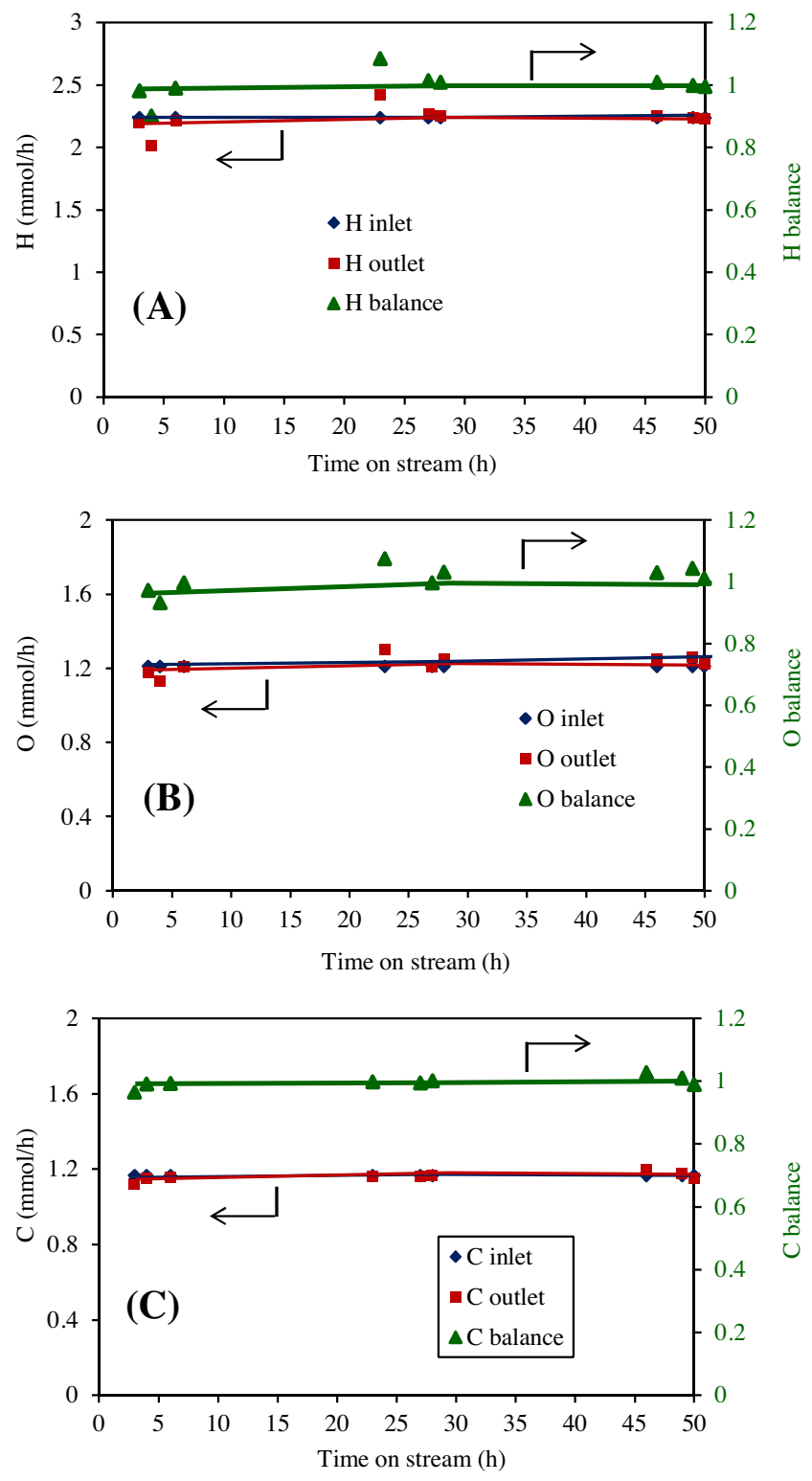

Fig. 17. Matter balance of the reaction. the catalytic test. For a given element $(A)$, the matter balance was calculated as follow:

Abalance $=\frac{A_{\text {inlet }}}{A_{\text {outlet }}}$

with A: $\mathrm{C}, \mathrm{O}$ or $\mathrm{H}$; $A_{\text {inlet }}$ : flux of element $A$ fed into the reactor $(\mathrm{mmol} / \mathrm{h}) ; A_{\text {outlet }}$ : flux of element $A$ quantified from the outlet gas $(\mathrm{mmol} / \mathrm{h})$

For both $\mathrm{O}$ and $\mathrm{H}$, the matter balance was buckled with the values close to unit along the reaction time. So, if there are other by-products which have not been detected by the $\mu$-GC used, their concentration must be negligible. For $\mathrm{C}$, despite the exclusion of carbonaceous deposition, the carbon balance was relatively buckled, meaning that the main components of the outlet gas were carbon monoxide and unreacted methane and carbon dioxide.

\section{Conclusions}

Using hydroxyapatite (HAP) as support, Ru and Pt supported catalysts were prepared by different methods and were investigated in the catalytic transformation of $\mathrm{CH}_{4}$ and $\mathrm{CO}_{2}$ to syngas. For both metals, catalysts prepared by incipient wetness impregnation (IWI) were found to be the most efficient. Ru-based catalysts were quickly deactivated in this reaction, because of coke deposition. On the other hand, Pt/HAP IWI catalysts were found to be active and stable for a long reaction time of $50 \mathrm{~h}$ of time-on-stream, under the reaction conditions used.

Water was experimentally identified and quantified as a byproduct of the reaction. Further work would be focused on the continuous quantification of this water, which may help for identifying the presence of side reactions. The influence of the basicity of HAP support, as well as the dispersion of active metal (Pt) on the catalytic performance will be also subject of future work.

\section{Acknowledgments}

The authors gratefully acknowledge colleagues at RAPSODEE Center for technical help.

\section{References}

[1] P.J. Coolcock, R.C. Brown, A review of cleaning technologies for biomass-derived syngas, Biomass Bioenergy 52 (2013) 54-84. 
[2] D.K. Kundiyana, R.L. Huhnke, M.R. Wilkins, Syngas fermentation in a 100-L pilot scale fermentor: design and process considerations, J. Biosci. Bioeng. 109 (5) (2010) 492-498.

[3] Y. Richardson, J. Blin, A. Julbe, A short overview on purification and conditioning of syngas produced by biomass gasification: catalytic strategies, process intensification and new concepts, Prog. Energy Combust. Sci. 38 (2012) 765-781.

[4] Anis Atikah Ahmad, Norfadhila Abdullah Zawawi, Farizul Hafiz Kasim, Assessing the gasification performance of biomass: a review on biomass gasification process conditions, optimization and economic evaluation, Renew. Sustain. Energy Rev. 53 (2016) 1333-1347.

[5] Nourredine Abdoulmoumine, Sushil Adhikari, Avanti Kulkarni, Shyamsundar Chattanathan, A review on biomass gasification syngas cleanup, Appl. Energy 155 (2015) 294-307.

[6] T. Zhu, M. Flytzani-Stephanopoulos, Catalytic partial oxidation of methane to synthesis gas over Ni-CeO2, Appl. Catal. A: Gen. 208 (2001) 403-417.

[7] V.R. Choudhary, S.D. Sansare, A.S. Mamman, Low-temperature selective oxidation of methane to carbon monoxide and hydrogen over cobalt-MgO catalysts, Appl. Catal. A: Gen. 90 (1992) L1-L5.

[8] Z. Boukha, M. Kacimi, M.F.R. Pereira, J.L. Faria, J. Luis Figueiredo, M. Ziyad, Methane dry reforming on Ni loaded hydroxyapatite and fluoroapatite, Appl. Catal. A: Gen. 317 (2007) 299-309.

[9] L. Pelletier, D.D.S. Liu, Stable nickel catalysts with alumina-aluminum phosphate supports for partial oxidation and carbon dioxide reforming of methane, Appl. Catal. A: Gen. 317 (2007) 293-298.

[10] I.G.O. Awa, Tunable ceria-zirconia support for nickel-cobalt catalyst in the enhancement of methane dry reforming with carbon dioxide, Catal. Commun. 52 (2014) 10-15.

[11] N. Wang, X. Yu, Y. Wang, W. Chua, M. Liu, A comparison study on methane dry reforming with carbon dioxide over $\mathrm{LaNiO}_{3}$ perovskite catalysts supported on mesoporous SBA-15, MCM-41 and silica carrier, Catal. Today 212 (2013) 98-107.

[12] P. Littlewood, X. Xie, M. Bernicke, A. Thomas, R. Schomäcker, $\mathrm{Ni}_{0.05} \mathrm{Mn}_{0.95} \mathrm{O}$ catalysts for the dry reforming of methane, Catal. Today 242 (2015) 111-118.

[13] H.P. Ren, Q.Q. Hao, W. Wang, Y.H. Song, J. Cheng, Z.W. Liu, Z.T. Liu, J. Lu, Z. Hao, High-performance $\mathrm{Ni}-\mathrm{SiO}_{2}$ for pressurized carbon dioxide reforming of methane, Int. J. Hydrogen Energy 39 (22) (2014) 11592-11605.

[14] R. Zanganeh, M. Rezaei, A. Zamaniyan, Preparation of nanocrystalline $\mathrm{NiO}-\mathrm{MgO}$ solid solution powders as catalyst for methane reforming with carbon dioxide: effect of preparation conditions, Adv. Powder Technol. 25 (2014) 1111-1117.

15] O. Ma, D. Wang, M. Wu, T. Zhao, Y Yoneyama, N. Tsubaki, Effect of catalytic site position: nickel nanocatalyst selectively loaded inside or outside carbon nanotubes for methane dry reforming, Fuel 108 (2013) 430-438.

[16] D. Liu, Y. Wang, D. Shi, X. Jia, X. Wang, A. Borgna, R. Lau, Y. Yang, Methane reforming with carbon dioxide over a $\mathrm{Ni} / \mathrm{ZiO}_{2}-\mathrm{SiO}_{2}$ catalyst: influence of pretreatment gas atmospheres, Int. J. Hydrogen Energy 37 (13) (2012) 10135-10144.

[17] A. Serrano-Lotina, L. Daza, Influence of the operating parameters over dry reforming of methane to syngas, Int. J. Hydrogen Energy 39 (2014) 4089-4094.

[18] A.R. González, YJ.O. Asencios, E.M. Assaf, J.M. Assaf, Dry reforming of methane on $\mathrm{Ni}-\mathrm{Mg}$-Al nano-spheroid oxide catalysts prepared by the sol-gel method from hydrotalcite-like precursors, Appl. Surf. Sci. 280 (2013) 876-887.

[19] C. Shi, A. Zhang, X. Li, S. Zhang, A. Zhu, Y. Ma, C. Au, Ni-modified $\mathrm{Mo}_{2} \mathrm{C}$ catalysts for methane dry reforming, Appl. Catal. A: Gen. 431-432 (2012) 164-170.

[20] N. Rahemi, M. Haghighi, A.A. Babaluo, M.F. Jafari, S. Khorram, Non-thermal plasma assisted synthesis and physicochemical characterizations of $\mathrm{Co}$ and $\mathrm{Cu}$ doped $\mathrm{Ni} / \mathrm{Al}_{2} \mathrm{O}_{3}$ nanocatalysts used for dry reforming of methane, Int. J. Hydrogen Energy 38 (2013) 16048-16061.

[21] D. Homsi, S. Aouad, C. Gennequin, A. Aboukais, E. Abi-Aad, A highly reactive and stable $\mathrm{Ru} / \mathrm{Co}_{6-x} \mathrm{Mg}_{\mathrm{x}} \mathrm{Al}_{2}$ catalyst for hydrogen production via methane steam reforming, Int. J. Hydrogen Energy 39 (2014) 10101-10107.
[22] M. Ghelamallah, P. Granger, Impact of barium and lanthanum incorporation to supported Pt and Rh on $\alpha-\mathrm{Al}_{2} \mathrm{O}_{3}$ in the dry reforming of methane, Fuel 97 (2012) 269-276.

[23] S. Chandra, Comprehensive Inorganic Chemistry, New age International, Delhi, 2004, pp. 80-81.

[24] A.I. Tsyganok, K. Suzuki, S. Hamakawa, K. Takehira, T. Hayakawa, Mg-A layered double hydroxide intercalated with $\left[\mathrm{Ni}(\text { edta) }]_{2}\right.$-chelate as a precursor for an efficient catalyst of methane reforming with carbon dioxide, Catal. Lett. $77(1-3)(2001) 75-86$.

[25] D. Pham Minh, M. Galera Martinez, A. Nzihou, P. Sharrock, Thermal behavior of apatitic calcium phosphates synthesized from calcium carbonate and orthophosphoric acid or potassium dihydrogen orthophosphate, J. Therm. Anal. Calorim. 112 (2013) 1145-1155.

[26] D. Pham Minh, G. Aubert, P. Gallezot, M. Besson, Degradation of olive oil mill effluents by catalytic wet air oxidation: 2-oxidation of $p$-hydroxyphenylacetic and $p$-hydroxybenzoic acids over Pt and Ru supported catalysts, Appl. Catal. B: Environ. 73 (2007) 236-246.

27] A. Peeters, L. Claes, I. Geukens, I. Stassen, D. de Vos, Alcohol amination with heterogeneous ruthenium hydroxyapatite catalysts, Appl. Catal. A: Gen. 469 (2014) 191-197.

[28] S. Akbayrak, P. Erdek, S. Özkar, Hydroxyapatite supported ruthenium(0) nanoparticles catalyst in hydrolytic dehydrogenation of ammonia borane: insight to the nanoparticles formation and hydrogen evolution kinetics, Appl. Catal. B: Environ. 142-143 (2013) 187-195.

[29] A. Lebugle, E. Zahidi, G. Bonel, Effect of structure and composition on the thermal decomposition of calcium phosphates $(\mathrm{Ca} / \mathrm{P}=1.33)$, React. Solids 2 (1986) 151-161.

[30] S. Lazic, S. Zec, N. Miljevic, S. Milonjic, The effect of temperature on the properties of hydroxyapatite precipitated from calcium hydroxide and phosphoric acid, Thermochim. Acta 374 (2001) 13-22.

[31] D. Pham Minh, N.D. Tran, A. Nzihou, P. Sharrock, Carbonate-containing apatite (CAP) synthesis under moderate conditions starting from calcium carbonate and orthophosphoric acid, Mater. Sci. Eng. C 33 (2013) 2971-2980.

[32] H. Sun, J. Huang, $\mathrm{H}$. Wang, J. Zhang, $\mathrm{CO}_{2}$ reforming of $\mathrm{CH}_{4}$ over xerogel Ni-Ti and Ni-Ti-Al catalysts, Ind. Eng. Chem. Res. 46 (2007) 4444-4450.

[33] E. Baktash, P. Littlewood, R. Schomäcker, A. Thomas, P.C. Stair, Alumina coated nickel nanoparticles as a highly active catalyst for dry reforming of methane, Appl. Catal. B: Environ. 179 (2015) 122-127.

[34] D. Pakhare, J. Spivey, A review of dry $\left(\mathrm{CO}_{2}\right)$ reforming of methane over noble metal catalysts, Chem. Soc. Rev. 43 (2014) 7813-7837.

[35] M. Usman, W.M.A.W. Daud, H.F. Abbas, Dry reforming of methane: influence of process parameters - a review, Renew. Sustain. Energy Rev. 45 (2015) $710-744$.

[36] C. Shi, P. Zhang, Role of MgO over $\gamma-\mathrm{Al}_{2} \mathrm{O}_{3}$-supported Pd catalysts for carbon dioxide reforming of methane, Appl. Catal. B: Environ. 170-171 (2015) 43-52.

[37] D.C. Carvalho, H.S.A. de Souza, J.M. Filho, A.C. Oliveira, A. Campos, E.R.C. Milet, F.F. de Sousa, E. Padron-Hernandez, A.C. Oliveira, A study on the modification of mesoporous mixed oxides supports for dry reforming of methane by Pt or Ru, Appl. Catal. A: Gen. 473 (2014) 132-145.

[38] M. Ghelamallah, P. Granger, Supported-induced effect on the catalytic properties of $\mathrm{Rh}$ and $\mathrm{Pt}-\mathrm{Rh}$ particles deposited on $\mathrm{La}_{2} \mathrm{O}_{3}$ and mixed $\alpha-\mathrm{Al}_{2} \mathrm{O}_{3}-\mathrm{La}_{2} \mathrm{O}_{3}$ in the dry reforming of methane, Appl. Catal. A: Gen. 485 (2014) 172-180.

[39] S. Ozkara-Aydinoglu, E. Ozensoy, A. Erhan Aksoylu, The effect of impregnation strategy on methane dry reforming activity of Ce promoted $\mathrm{Pt} / \mathrm{ZrO}_{2}$, Int. J. Hydrogen Energy 34 (2009) 9711-9722.

[40] M.S. Aw, I.G.O. Crnivec, P. Djinovic, A. Pintar, Strategies to enhance dry reforming of methane: synthesis of ceria-zirconia/nickel-cobalt catalysts by freeze-drying and NO calcination, Int. J. Hydrogen Energy 39 (2014) 12636-12647.

[41] P. Djinovic, I.G.O. Crnivec, A. Pintar, Biogas to syngas conversion without carbonaceous deposits via the dry reforming reaction using transition metal catalysts, Catal. Today 253 (2015) 155-162. 